\title{
IMUNIDADE TRIBUTÁRIA À INCIDÊNCIA DOS IMPOSTOS INDIRETOS NA AQUISIÇÃO DE BENS E SERVIÇOS POR ENTIDADES DE ASSISTÊNCIA SOCIAL: ESTUDO DOGMÁTICO E ANÁLISE DA JURISPRUDÊNCIA CONSTITUCIONAL SOBRE O FENÔMENO DA REPERCUSSÃO ECONÔMICA
}

\author{
TAX IMMUNITY ON INDIRECT TAXES IN THE ACQUISITION OF GOODS AND SERVICES BY
}

WELFARE ORGANIZATIONS: DOGMATIC STUDY AND ANALYSIS OF CONSTITUTIONAL CASE

LAW ON THE PHENOMENON OF ECONOMIC REBOUND

Alexandre Yoshio Hayashi*

\begin{abstract}
Resumo:
A escolha do tema é justificada pela polêmica acerca da extensão da imunidade tributária impostos se o vendedor não é imune, mas o comprador é entidade de assistência social imune por força do art. 150, inciso VI, alínea "c" da Constituição da República. A proposta do presente estudo é problematizar a questão desde as premissas que embasam a classificação dos tributos em "diretos" e "indiretos" e sua implicação no reconhecimento dos contribuintes "de fato" e "de direito", cujas origens remontam o próprio desenvolvimento histórico-metodológico da disciplina "Direito Tributário" e sua autonomia da "Ciência" das Finanças. Coerente com as colocações propedêuticas, faz-se observações específicas ao art. 150, inciso VI, alínea "c" da Constituição da República, de acordo com a doutrina e a jurisprudência, a respeito da pertinência jurídica do fenômeno da "repercussão econômica" na classificação dos tributos em "diretos" e "indiretos" e sua consequência no reconhecimento da imunidade tributária às entidades de assistência social quando estas ostentarem a condição de contribuintes "de fato" na aquisição de bens e serviços de fabricantes, vendedores e prestadores não-imunes.
\end{abstract}

Palavras-chave: Ciência do Direito Tributário. Ciência das Finanças. Interpretação Econômica. Tributos Indiretos. Contribuinte de Fato. Imunidades Tributárias. Entidades de Assistência Social. Jurisprudência Constitucional.

\begin{abstract}
:
The subject is justified by the controversy about the extent of tax exemption to sellers, if the buyer is a social assistance entity immune by virtue of art. 150, VI, "c" of the Federal Constitution. The purpose of this paper is to discuss the issue from the underlying assumptions of tax tipology on "direct" and "indirect" and the implication in recognition of taxpayers "in fact" and "in-law", whose origins were in the historical and methodological development of the "Tax Law" subject and in the autonomy of the "science" of Finances. Consistent with propaedeutic placements,
\end{abstract}

Graduado em Direito, com Concentração em Direito de Empresa (Administração Empresarial e Tributária), pela Faculdade de Direito da Universidade de São Paulo - USP. Pós-Graduado, com Título de Especialista em Direito Tributário, pela Faculdade de Direito da Universidade de São Paulo - USP. Este artigo é adaptação da dissertação, aprovada com nota máxima, apresentada para a obtenção do título de especialista, com bolsa concedida pela Fundação de Apoio à Universidade de São Paulo - FUSP. Contato: milescritos@ uol.com.br. 
specific comments to article 150, VI, "c" of the Federal Constitution, according to the doctrine and case law regarding the legal relevance of the phenomenon of "economic rebound" in the classification of taxes on "direct" and "indirect" and the consequence in recognition of tax immunity to social assistance entities when they bear the capacity of taxpayers "actually" in the acquisition of goods and services from non-immune manufacturers, sellers and providers.

Keywords: Science of the Tax Law. Economic Interpretation. Indirect Taxes. Taxpayer de Facto. Tax Immunities. Foundations of Social Assistance. Constitutional Jurisprudence.

\section{Introdução}

A proposta deste estudo é expor o desenvolvimento histórico da Ciência do Direito Tributário, ${ }^{1}$ com o objetivo de demonstrar $(i)$ a inaplicabilidade da consideração econômica como critério de interpretação da norma e dos fatos jurídicos tributários; (ii) a impraticabilidade da classificação dos tributos em "diretos" e "indiretos", segundo o preceito da "repercussão econômica"; ${ }^{2}$ para (iii) examinar criticamente a doutrina e a jurisprudência sobre o reconhecimento da imunidade às entidades de assistência social quando invocam a condição de contribuinte "de fato" em operações de aquisição de bens e serviços contratados com vendedores, fabricantes e prestadores não imunes.

Dessa forma, impõe-se como premissa demonstrar que para o exame do fenômeno jurídico tributário foi preciso desenvolver uma metodologia própria, longe de ser satisfeita pelos antigos preconceitos da Ciência das Finanças, que pretendia descrever fenômenos tão diversos (econômico-financeiros e jurídicos) com métodos, no mínimo, marcados pelo sincretismo (fazendo miscelânea de conceitos jurídicos e metajurídicos econômico-financeiros).

1 "O curso de Direito é, infelizmente, deficiente na parte de Teoria Geral do Direito. Depois, vamos aprendendo aos trancos e barrancos, e aprendendo mal. Se aprendêssemos melhor a Teoria Geral do Direito na Faculdade, o número de questões discutidas em juízo, de atritos, controvérsias e contendas seria menor. Exemplificando com o nosso curso, o maior número de questões discutidas gira em torno da Teoria Geral do Direito, e não do Direito Tributário. Poder-se-á verificar que $80 \%$ das discussões não serão sobre matéria de Direito Tributário, mas sobre teoria geral do direito. Matéria de Direito Tributário, praticamente ninguém discute; o que se discute é matéria de teoria geral de direito. Esta realmente é a matéria fundamental, envolve questões propedêuticas, preliminares, introdutórias" (ATALIBA, Geraldo. Propedêutica Jurídica. In: _. (Coord.). Elementos de direito tributário: notas taquigráficas do III Curso de Especialização em Direito Tributário, realizado na Pontifícia Universidade Católica de São Paulo. São Paulo: Revista dos Tribunais, 1978, p. 13).

2 Alfredo Augusto Becker, baseando-se em um célebre artigo de (LAUFENBURGER, H. La distinzione fra imposte dirette ed indirette. Rivista di Diritto Finanziario e Scienza delle Finanze e Rivista Italiana di Diritto Finanziario, Milano, mar. de 1954, p. 3-18), manifesta-se no sentido de que aceitar o critério da repercussão econômica tratar-se-ia de uma simplicité de l'ignorance, salientando que a clássica distinção dos tributos por tal critério foi abolida sob o tríplice plano: técnico, administrativo e jurídico (Cf. BECKER, Alfredo Augusto. Teoria geral do direito tributário. São Paulo: Lejus, 1998. p. 539-543). 
Sucede que a "repercussão econômica", pretendendo descrever fenômeno estritamente econômico, não pode interferir na análise dos fatos e das normas jurídicas, afastando-se, desse modo, o princípio da realidade econômica na interpretação da norma e dos fatos jurídicos tributários. ${ }^{3}$

De fato, assim não se discutiria o reconhecimento do contribuinte "de fato," porquanto o fenômeno da repercussão econômica não se presta à classificação dos tributos em "diretos" e "indiretos".

Mas aderente à realidade hic et nunc, faz-se, por último, necessário acompanhar criticamente os pronunciamentos dos Ministros do Supremo Tribunal Federal diante do contencioso instaurado entre o Estado e as entidades de assistência social, longe de serem uniformes e pacíficos.

A pesquisa irá envolver $(i)$ análise histórica da disciplina "Direito Tributário" e de seus métodos no Brasil; (ii) método comparado, que procure justificar a consideração econômica (ou análise econômica); (iii) discussão dialética, com análise crítica das posições antagônicas na doutrina pátria, problematizando a pertinência da repercussão econômica no fenômeno jurídico-tributário; e (iv) pesquisa jurisprudencial, que não se perderá na mera coletânea de precedentes, mas aproveitando-se as teses e os princípios gerais adotados, explicitando-se a aplicação inteligente do direito positivo e respeitando-se a autoridade dos Tribunais.

Finalmente, insta esclarecer a orientação metodológica da pesquisa do tema: entre os enfoques que podem ser aplicados na ciência do direito, privilegiou-se o estudo de cunho dogmático, ${ }^{5}$ delimitando-se os questionamentos à obtenção de respostas legais e às considerações das discussões exegéticas-doutrinárias para as necessidades

3 Na melhor das hipóteses, o fenômeno da repercussão econômica pode estabelecer um vínculo de natureza privada entre o contribuinte "de fato" e o contribuinte "de iure", sendo aquele titular de direito de regresso se suportou valor indevido, conforme sugere (BOTTALLO, Eduardo Domingos. Restituição de impostos indiretos. Revista de Direito Público: Caderno de Direito Tributário, n. 22, p. 320), republicado com o título (Repetição do indébito tributário e o art. 166 do código tributário nacional. Revista de Direito Tributário, $\mathrm{n}$. 75, p. 119-225) e na Revista da Faculdade de Direito da Universidade de São Paulo, v. 94, p. 251-262, jan./ dez/ 1999).

4 "Um panorama da História da Ciência do Direito tem a virtude de nos mostrar como esta ciência, em diferentes épocas, se justificou teoricamente" (FERRAZ JÚNIOR, Tércio Sampaio. A ciência do direito. 2. ed. São Paulo: Atlas, 1980. p. 18). Corrobora a vetusta lição de Waldemar Ferreira: "Nenhum jurista pode dispensar o contingente do passado a fim de bem compreender as instituições jurídicas dos dias atuais. Ninguém é capaz de dar passo à vanguarda, adiantando um sem deixar o outro pé na retaguarda. Diferentemente não se realizam caminhadas. De cada instituto se ministram, nas cátedras universitárias, retrospecto sucinto. Matéria inexiste que se possa explicar clara e seguramente sem a antecedência de notícia, abreviada ao menos, de seu desenvolvimento doutrinário e legislativo até adquirir seus aspectos contemporâneos" (História do direito brasileiro. 2. ed. São Paulo: Saraiva, 1962. v. 1, p. 1.).

5 Cf. FERRAZ JÚNIOR, Tércio Sampaio. Introdução ao estudo do direito: técnica, decisão, dominação. 2. ed. São Paulo: Atlas, 1996. p. 39-51. 
operacionais do sistema jurídico, porquanto o problema fundamental da ciência jurídica é a questão da decidibilidade. ${ }^{6}$

Assim, houve uma opção metodológica de não se estudar o direito apenas por uma emoção estética (mormente "porque ninguém leva um texto de lei para um momento de lazer, nem para um momento de intimidade, a não ser que seja doido" "7), abdicando-se das especulações de natureza metajurídicas (antropológicas, filosóficas, sociológicas, econômico-financeiras), próprias de uma investigação com enfoque zetético.

Deveras, o tema do presente estudo insere-se justamente na evolução metodológica da disciplina "Direito Tributário" no Brasil, delimitando-se o objeto de estudo à Teoria do Direito Tributário aplicada ao direito positivo brasileiro vigente.

\section{Direito Tributário e Realidade Econômica}

No campo empírico tributário, a discussão acerca da aplicação da análise econômica sobre normas e fatos jurídicos parte de "sistemas de fundamentos óbvios": ${ }^{8}$ por exemplo, de um lado $(i)$ o senso comum e parte dos estudiosos do direito observam que alguns tributos, de fato, "repercutem", sendo indubitável o reconhecimento jurídico do contribuinte "de fato" e a validade da classificação dos tributos em "diretos" e "indiretos"; por outro lado, (ii) há aqueles que repugnam essa assertiva por ser "óbvia" a impertinência de conceitos metajurídicos (verbi gratia, econômicos) na intelecção do fenômeno jurídico tributário, sem maior profundidade para justificar essa afirmação apriorística. ${ }^{9}$

6 Cf. FERRAZ JÚNIOR, Tércio Sampaio. A ciência do direito... cit., p. 43-47; Introdução ao estudo... cit., p. 89-92; Função social da dogmática jurídica. São Paulo: Max Limonad, 1998, p. 18 a 24. "A Ciência do Direito, enquanto se destina ao estudo das normas, ordenando-as segundo princípios, e tendo em vista sua aplicação, toma o nome de Dogmática Jurídica, conforme clássica denominação. [...] O Direito não é constituído apenas com fins explicativos. [...] A pesquisa, no mundo jurídico, visa sempre a um momento da aplicação. O sociólogo poderá estudar o fenômeno jurídico sem qualquer preocupação de ordem prática, buscando-se descobrir os nexos causais ou as constantes que existem entre o fato social e o mundo jurídico. O jurista, porém, como cientista do Direito, não poderá jamais parar ou suspender a sua pesquisa, no plano meramente compreensivo, porquanto, no mundo jurídico, a compreensão se converte necessariamente em normação. [...] Toda colocação teorética de um princípio jurídico representa momento condicionante da colocação de um princípio prático de ação" (REALE, Miguel. Lições preliminares de direito. 23. ed. São Paulo: Saraiva, 1996, p. 317-319).

7 Cf. GRAU, Eros Roberto. Interpretação da lei tributária e segurança jurídica. Conferência ao XXIV Congresso de Direito Tributário - IDEPE, em 22.10.2010. Revista de Direito Tributário, v. 113, p. 220.

8 “O Direito Tributário está em desgraça e a razão deve buscar-se - não na superestrutura - mas precisamente naqueles fundamentos 'óbvios' para merecerem a análise crítica” (BECKER, Alfredo Augusto. Teoria geral... cit., p. 11).

9 "No País, duas correntes de ensino são bem detectáveis, na propedêutica do direito tributário: aquela corrente dos que reduzem sua fenomenologia, pelo prisma jurídico, a objeto de uma ciência instrumental, desnecessário se fazendo o conhecimento da economia, contabilidade, finanças públicas e ciências que o influenciam, e a corrente dos que universalizam o fenômeno tributário, interpretando a instrumentalidade do direito à luz de todas as ciências que o impactam. À evidência, a produção literária, tanto dos formalistas 
Diante de tal radicalismo que nada enobrece e a todos se esmaece, propomos estudar se o "direito" encerra em si diversos objetos com naturezas correspondentemente diferentes, autorizando, por isso, a aplicação de sincretismo de objetos de outras ciências (sociologia, psicologia, história, política, economia etc); ou se o objeto jurídico é uma realidade específica que pode ser apreendido por um domínio científico.

\section{1. - Subsídios da Ciência das Finanças}

Sem esgotarmos a pesquisa doutrinária, a guisa de exemplificação, sondemos a literatura de Aliomar Baleeiro: sua Uma Introdução à Ciência das Finanças demonstra que de naturezas diversas são os objetos da disciplina que antecedeu o Direito Tributário, que pretendia imprimir cientificidade a um estudo da atividade financeira do Estado, da Economia Política, da Política Fiscal e do Direito Tributário; ${ }^{10}$ em seu Direito Tributário Brasileiro, problematiza a questão da autonomia da Ciência das Finanças, do Direito Financeiro e do Direito Tributário; ${ }^{11}$ e, finalmente, em sua obra Limitações Constitucionais ao Poder de Tributar, assevera que a Ciência das Finanças contém subsídios para a intelecção de fenômenos jurídicos, ${ }^{12}$ defendendo o sincretismo de objetos na interpretação jurídica com o aproveitamento de "subsídios" de Ciência das Finanças.

quanto dos estruturalistas, termina por veicular a pessoal visão de seus autores, com que não poucas vezes a divergência doutrinária ultrapassa os limites da investigação científica, adentrando o campo das preferências e antipatias temáticas" (MARTINS, Ives Gandra Silva. Prefácio. In: AMARO, Luciano. Direito tributário brasileiro. 17. ed. São Paulo: Saraiva, 2011.p. 11). Cf. "Economia e Sua Repercussão no Direito Tributário", in Revista da Faculdade de Direito da Universidade de São Paulo, v. 101, 2006, p. 939-977.

10 Revista e atualizada por F. B. Novelli, 14. ed., Rio de Janeiro: Forense, 1993. Em verdade, a produção "doutrinária" de Ciência das Finanças no Brasil reproduziu os mesmos objetos e métodos da disciplina desenvolvida na Europa: “Les autres considèrent les phénomènes financiers tels qu'ils se présentent em fait, dans leur milieu politique, social, économique, juridique; ils les étudient comme des phénomènes complexes, avec tous les facteurs qui les conditionnent: ils prétendent faire ainsi de la science des finances. C'est le point de vue qui a mes préférences" (JÈZE, Gaston. Cours de science et legislation financiers. 6. ed. Paris: Marcel Giard, 1923. p. 18-19).

11 BALEEIRO, Aliomar. Direito tributário brasileiro. 11. ed. rev. e atual. por F. B. Novelli. Rio de Janeiro: Forense, 1999. p. 1 a 10.

12 . Limitações constitucionais ao poder de tributar. Revista, complementada à luz da Constituição de 1988 até a Emenda Constitucional n. 10/1996; e comentada por M. A. M. Derzi. Rio de Janeiro: Forense, 1998. p. 705-709; 743-744. Dessa última sequência de páginas, podemos explicitar a posição doutrinária de Aliomar Baleeiro, assim: "Ainda que convictos da autonomia entre as duas disciplinas afins, cremos que o Direito Fiscal não pode prescindir dos subsídios teóricos e técnicos da Ciência das Finanças, ou, como ensina Giannini: 'Il diritto finanziario inoltre illustra il meccanismo giuridico più idoneo per tradurre in prattica i dettami della scienza finanziaria; le leggi della finanza servono di guida al legislatore e possono essere, alcune volte, utile strumento per l'interpretazione delle leggi finanziarie"' (p. 744). Reiterando esse posicionamento, mas utilizando-se de outro texto de doutrina de Giannini, diametralmente oposto à citação ora transcrita, encontramos a seguinte passagem do livro Direito Tributário Brasileiro (nota 12): "Giannini falou da 'deletéria fusão e confusão do Direito com a Ciência das Finanças', ou da 'estrutura jurídica com a essência econômica'. Nem fusão, nem confusão, por certo, mas vinculação íntima e originária, como Gangemi acentuou em réplica à afirmativa do Prof. Romanelli, em 1959, de que 'Ciência das Finanças 
Com efeito, o desenvolvimento doutrinário do ramo didaticamente autônomo "Direito Tributário" justificou-se teoricamente com os primeiros estudos específicos a partir da promulgação do Código Tributário Alemão (Reichsabgabenordnung - RAO, de 13 de dezembro de 1919), elaborado a partir do Anteprojeto de ENNO BECKER, Presidente da $4^{\text {a }}$ Seção da Corte Suprema Financeira do Reich, que se valeu dessa autoridade para positivar a consideração econômica na interpretação das normas e dos fatos jurídicos tributários em seu parágrafo 4. ${ }^{\circ}$, que preceitua o seguinte: “a interpretação das leis tributárias deve ter em vista o seu objetivo, seu significado econômico e o desenvolvimento das relações". ${ }^{13}$

Desde a promulgação do Código Tributário Alemão e a partir da construção jurisprudencial da Corte Suprema Alemã e doutrinária de Enno Becker, a consideração econômica gozou de prestígio não só entre os estudiosos de Direito Tributário na Alemanha, repercutindo também no exterior. ${ }^{14}$

e Direito Financeiro têm por objeto ordens de fatos completamente distintos'. Já o contestara, no Brasil, há mais de meio século, C. Maximiliano ['Em verdade não se presume inteligência dos textos positivos contrária aos princípios científicos; estes abrem o caminho para o exegeta. Se assim é de concluir a respeito das ciências em geral, com abundância, mais de razão do mesmo modo há de se afirmar em se tratando de ciência das finanças, matéria intimamente conexa com o Direito...']" (p. 5 [com inserção da nota de rodapé n. 7]; o texto em italiano de Giannini encontra-se reproduzido na p. 17 da mesma obra).

13 "Bei der Auslegung der Steuergesetze sind ihr Zweck, ihre wirtschafliche Bedeutung und die Entwicklung der Verhaeltnisse zu beruecksichtigen". Transcrevemos a tradução de (NOGUEIRA, Liz Coli Cabral. A consideração econômica no direito tributário. In: NOGUEIRA, R. B. (Dir.). (Col.). Estudos tributários. São Paulo: Resenha Tributária, 1974. p. 354). Cf. BEISSE, Heinrich. Interpretação. In: NOGUEIRA, R. B (dir.) e (col.). Estudos tributários. São Paulo: Resenha Tributária, 1974. p. 39-44; do mesmo autor, (BEISSE, Heinrich. O critério econômico na interpretação das leis tributárias segundo a mais recente jurisprudência alemã. In: MACHADO, Brandão (Coord.). Direito tributário: estudos em homenagem ao prof. Ruy Barbosa Nogueira. São Paulo: Saraiva, 1984. p. 5-44); ROTHMANN, Gerd Willi. O princípio da legalidade tributária. In: NOGUEIRA, Ruy Barbosa (Org.). Direito tributário: estudos de casos e problemas. São Paulo: José Bushatsky, Editor, 1974. p. 137-180; AMARO, Luciano. Direito tributário brasileiro. 17. ed. São Paulo: Saraiva, 2011. p. 249-255, 327; HUGO DE BRITO MACHADO, Temas de Direito Tributário, São Paulo: Revista dos Tribunais, 1993, p. 74; ALCIDES JORGE COSTA, "Direito Tributário e Direito Privado", in Direito Tributário - Estudos em Homenagem ao Prof. Ruy Barbosa Nogueira. Coord. Brandão Machado. São Paulo: Saraiva, 1984, p. 221 a 237; JOSÉ EDUARDO SOARES DE MELO, Curso de Direito Tributário, São Paulo: Dialética, 1997, p. 151 a 153; "Interpretação e Integração da Legislação Tributária", in Curso de Direito Tributário (coord. I. G. Silva Martins). 7. ed., São Paulo: Saraiva, 2000, p. 151 a 155; JOSÉ MORSCHBACHER, A Restituição dos Impostos Indiretos cit.; JOHNSON BARBOSA NOGUEIRA, A Interpretação Econômica no Direito Tributário, São Paulo: Resenha Tributária, 1982; SACHA CALMON NAVARRO COELHO, "Interpretação Econômica em Direito Tributário - Prevalência do Conteúdo sobre a Forma - Impossibilidade no Direito Brasileiro - Princípio da Legalidade", in Revista de Direito Tributário, n. 55, p. 180 a 193; ZELMO DENARI, "A Interpretação Econômica do Nosso Sistema Tributário", in Revista de Direito Tributário, n. 55, p. 343 a 351; MIZABEL ABREU MACHADO DERZI, "Finalmente, um retorno a Aliomar Baleeiro? O falso dilema entre interpretação jurídica ou econômica"; "A interpretação impropriamente chamada 'econômica' e o respeito às formas, conceitos e institutos jurídicos. A tensão entre igualdade e segurança jurídica”, in ALIOMAR BALEEIRO, Limitações Constitucionais ao Poder de Tributar, Rio de Janeiro: Forense, 1998, p. 301 a 306; 644 a 647 e 729 a 731.

14 Conforme anota JOSÉ EDUARDO MONTEIRO DE BARROS: "A influência dessa teoria não ficou na Alemanha. A Suíça logo se incorporou ao rol daqueles que adotavam a chamada interpretação econômica e 
No Brasil, os primeiros doutrinadores (Aliomar Baleeiro, Amílcar de Araújo Falcão, Ruy Barbosa Nogueira), socorrendo-se da literatura estrangeira, incorporaram a doutrina da consideração econômica, defendendo a utilização de "subsídios" de Ciência das Finanças na interpretação das normas e dos fatos jurídicos tributários. ${ }^{15}$

Neste contexto, é prestigiada a noção de "repercussão econômica", ${ }^{16}$ emprestada da "Ciência" das Finanças, isto é, compreendida como o repasse do encargo

o seu maior arauto foi Blumenstein. A Itália, através da plêiade de juristas, todos herdeiros da famosa Escola de Pávia - Griziotti criticou a teoria da interpretação econômica, por outros motivos, porque inventou uma interpretação econômica um pouco mais ampla, a chamada interpretação funcional do direito tributário -, com exceção de Griziotti, seguiu a teoria da interpretação econômica. Os seguidores de Griziotti também adotaram, principalmente Vanoni, que mais tarde, foi estudar na Alemanha e se tornou, depois, Ministro das Finanças, na Itália, e Dino Jarach, que é italiano, obrigado a deixar a Itália, acabou se radicando na Argentina" ("Interpretação Econômica em Direito Tributário", in Interpretação no Direito Tributário, Org. B. Ribeiro de Barros, Coord. G. Ataliba. São Paulo, Saraiva-EDUC, 1975, p. 173).

15 "Essa teoria da interpretação econômica consolidou-se, definitivamente, na Alemanha, ganhou novas fronteiras, espalhou-se pela Suíça, entrou na Itália e, evidentemente, tinha que chegar ao Brasil. E, no Brasil, além de alguns estudos de Rubens Gomes de Souza - que não diz expressamente se aceita ou não essa teoria da interpretação econômica - é possível afirmar que essa teoria ganhou certa aceitação, porque algumas passagens da obra do autor acima referido indicam a acolhida dessa teoria e, especialmente, o Prof. Amílcar de Araújo Falcão, aceita-a plenamente" (JOSÉ EDUARDO MONTEIRO DE BARROS, "Interpretação Econômica", in Interpretação no Direito cit., p. 173.) Cf. RICARDO LOBO TORRES, "As Influências Germâmicas no Direito Financeiro e Tributário Brasileiro", in Revista de Direito Tributário, v. 73, p. 76 a 85; ALMÍCAR ARAÚJO FALCÃO, “Autonomia dos Governos Locais em Matéria Tributária”, in Revista de Direito Administrativo, n. 47, p. 7, "Interpretação e Integração da Lei Tributária”, in Revista de Direito Administrativo, n. 40, p. 24; Fato Gerador da Obrigação Tributária. Rio de Janeiro: Edições Financeiras, 1964, p. 70; Introdução ao Direito Tributário Brasileiro. Rio de Janeiro: Forense, 1999, p. 67, 68, 73 e 74.

16 Ainda que de maneira sintética, não podemos omitir outros critérios imaginados pela doutrina para, teoricamente, justificar uma classificação dos tributos em direitos e indiretos. Além do critério da repercussão econômica (indubitavelmente o mais difundido), também se estribou a referida classificação segundo os critérios $(i)$ do lançamento (ato jurídico administrativo que declara o acontecimento do fato jurídico tributário, bem como identifica o sujeito passivo da obrigação tributária, determina a base de cálculo e a alíquota aplicável, formaliza o crédito tributário e estipula os termos de sua exigibilidade); (ii) do "fato gerador"; e (iii) dos campos econômicos imponíveis. Adotando-se o critério do (i) lançamento, seriam diretos os tributos cuja arrecadação dependesse do ato jurídico administrativo que verte em linguagem competente a ocorrência do fato jurídico tributário e suas implicações; e, ao revés, seriam indiretos os tributos cujo recolhimento prescindisse deste ato prévio. Outro critério pesquisa a materialidade da regramatriz de incidência, conhecido como critério do (ii) "fato gerador", originalmente concebido por Giannini (Il Concetti, p. 84, apud GERALDO ATALIBA, Apontamentos de Ciência das Finanças, Direito Financeiro e Tributário. São Paulo, Revista dos Tribunais, 1969, p. 203), difundido no Brasil por RUBENS GOMES DE SOUZA (Compêndio de Legislação Tributária cit., p. 127 e 128), segundo o qual os impostos diretos incidiriam sobre manifestações permanentes ou duráveis da capacidade contributiva (exempli gratia, "ser proprietário de...", "auferir renda"), enquanto que os impostos indiretos, sobre situações instantâneas ou que possam ser isoladas no tempo, denunciando mediata e indiretamente essa mesma capacidade econômica ("consumir mercadoria ou prestação de serviço"). O critério de classificação segundo (iii) os campos econômicos de imposição tributária, faz considerações sobre: a renda, o consumo e o patrimônio. Sucede desse critério a corriqueira classificação do imposto sobre a renda como imposto direto, porquanto seriam onerados exclusivamente os contribuintes legais, os beneficiários do acréscimo ou acúmulo de riqueza. Ao revés, o imposto sobre o consumo caracterizaria imposto indireto porque o contribuinte legal (verbi gratia, o vendedor de canetas do bazar), obrigado a reter o tributo, não se identifica com a pessoa efetiva e diretamente visada pela manifestação de capacidade econômica, traduzida pelo gasto, consumo ou 
financeiro da obrigação tributária pelo sujeito passivo à pessoa que não realizou o fato jurídico tributário.

Aliomar Baleeiro sintetizou a teoria da "repercussão econômica" (também denominada "translação"), bem como sua implicação no reconhecimento dos contribuintes "de direito" e "de fato". ${ }^{17}$

A "repercussão econômica" identifica-se com a transferência do encargo econômico-financeiro da obrigação tributária pelo sujeito passivo legalmente eleito (contribuinte de direito) para terceiro que efetivamente não realizou o fato jurídico tributário (contribuinte de fato). ${ }^{18}$

A figura do contribuinte "de fato" é, portanto, conceitualmente ligada ao fenômeno da "repercussão econômica" do tributo.

Ordinariamente, isto ocorre, verbi gratia, quando o contribuinte legalmente eleito (por exemplo, o produtor de chapas de aço) transfere o ônus do tributo a terceiro (adquirente da referida chapa de aço), que sofre a "incidência econômica"19 da norma tributária sem ter realizado o fato jurídico tributário, mediante, comumente, a agregação, ao preço de venda, do valor devido a título de imposto.

Devemos estar atentos à observação de Aliomar Baleeiro, que salientava casos em que a repercussão poderia ser parcial, em superficie $e^{20}$ ou nenhuma: nem sempre

dispêndio de renda (o adquirente da caneta). Cf. ALIOMAR BALEEIRO, Uma Introdução à Ciência das Finanças cit., p. 262 a 264; LUIS DIAS FERNANDES, Repetição do Indébito Tributário, Dissertação de Mestrado apresentada perante o Departamento de Direito Econômico e Financeiro da Faculdade de Direito da Universidade de São Paulo em 1995, sob a orientação do Professor Doutor Alcides Jorge Costa, p. 38 a 49; GASTON JÈZE, Cours Élémentaire de Science des Finances et de Législation Francière cit., p. 701-705; H. LAUFENBURGER, "La Distinzione fra Imposte Dirette ed indirette", in Rivista di Diritto Finanziario cit., p. 3 a 18; JOSÉ MORSCHBACHER, A Restituição dos Impostos Indiretos cit., p. 30 a 66; HUGO DE BRITO MACHADO SEGUNDO, Repetição do Tributo Indireto - Incoerências e Contradições, São Paulo: Malheiros, 2011.

17 Uma Introdução à Ciência das Finanças cit., p. 151 a 164.

18 "No Direito Tributário, e mais especificamente na temática da repetição do indébito, o conceito de 'contribuinte de fato' realmente é relativo, conquanto a maior parte das discussões se faz em apenas uma das etapas do ciclo do tributo" (MARCELO FORTES DE SERQUEIRA, Repetição do Indébito Tributário - Delineamentos de Uma Teoria. São Paulo, Max Limonad, 2000, p. 390).

19 Cf. ALFREDO AUGUSTO BECKER, Teoria Geral cit., p. 533.

20 "Admite-se também a repercussão em superficie, quando a carga é suportada pelo contribuinte de direito, pelo de fato e por cada um dos intermediários (atacadista, retalhista etc) [...] Lord Mansfield (1766), num discurso em época anterior às obras de Verri e Adam Smith, comparou o imposto sobre um elemento do mercado como uma pedra que caísse num lago e produzisse círculos concêntricos de agitação das águas até os pontos mais distantes. A idéia subjacente nessa imagem serviu de fundamento à teoria da difusão dos impostos, que teve por defensores Andrew Hamilton (1790), Verri e outros, dos quais o mais expressivo foi Canard (1801). Este entendia que a carga dos impostos se distribuía por igual entre todos os vendedores e compradores através de repercussões recíprocas e para terceiros, de sorte que, no fim, o ônus se diluiria por toda a coletividade. O sacrifício se pulverizaria entre todos os membros desta. 'A carga do imposto acaba por anular-se e não ser suportada por ninguém', concluía Canard com otimismo. [...] Alguns economistas e homens d'Estado participaram da crença de Canard. Mas há muitos anos há financistas que não repute 
o contribuinte de direito logra êxito no repasse do encargo tributário, devendo o estudioso do fenômeno da repercussão econômica meditar sobre as teorias econômicas da formação de preço, considerando todas as variáveis de um mercado, entre elas a rigidez ou a elasticidade da demanda ou da oferta de um determinado bem econômico. ${ }^{21}$

Deveras, a teoria econômica verifica que em algumas hipóteses de monopsônio - situação de mercado em que existe apenas um comprador para um determinado bem ${ }^{22}$ - a "repercussão econômica" pode se realizar "para trás", isto é, do comprador para o vendedor, que suporta no todo ou em parte o encargo econômicofinanceiro da obrigação tributária. ${ }^{23}$

\section{2. - Pertinência Jurídica da "Repercussão Econômica"}

O que prejudica o interesse jurídico sobre a consideração econômica da repercussão dos tributos é a produção assistemática e sincrética que desqualifica o suposto estatuto epistemológico de cientificidade da "Ciência" das Finanças, disciplina essa pretensamente formadora de subsídios para a interpretação das normas e dos fatos jurídicos tributários. $^{24}$

Mesmo entre os teóricos de "Ciência" das Finanças, ao que se refere ao nosso tema de estudo, Edwin R. A. Seligman aduzia a absoluta falta de exatidão das teorias da repercussão econômica, ${ }^{25}$ demonstrando o quão contingente é a ocorrência desse fenômeno econômico (variando em razão da durabilidade do bem econômico; da situação monopolística ou de livre concorrência do mercado; da técnica do imposto - se percute genérica ou exclusivamente sobre determinada operação ou bem econômico; da rigidez ou elasticidade da demanda do objeto tributado; dos efeitos das leis de rendimentos

falácia a teoria da difusão, tal como foi exposta. Ela, porém, serviu para atrair a atenção de estudiosos no sentido dos efeitos remotos do tributo, efeitos que realmente não se limitam às reações entre compradores e vendedores iniciais, os contribuintes de direito e de fato" (Uma Introdução à Ciência cit., p. 154 e 158).

21 Cf. GUILHERME ADOLFO MENDES, "Direito e Tradução", in Vilém Flusser e Juristas - Comemoração dos 25 Anos do Grupo de Estudos de Paulo de Barros Carvalho, Coord. Florence Haret e Jerson Carneiro, São Paulo: Noeses, 2009, p. 225 e 226.

22 Cf. PAUL ANTHONY SAMUELSON e WILliAN D. NORDHAUS, Economics, McGraw-Hill, 1992, trad. port. de E. Nobre Fontana e J. Pires Gomes, Economia. Lisboa, McGraw-Hill, 14. edição, 1993, p. 301 e 302 .

23 Cf. ALIOMAR BALEEIRO, Uma Introdução à Ciência cit., p. 154.

24 Cf. "Economia e Sua Repercussão no Direito Tributário", in Revista da Faculdade de Direito. Universidade de São Paulo, v. 101, 2006, p. 939-977.

25 São as primeiras linhas da Théorie de la Répercussion et de L'incidence de L'impôt (trad. franc. de L. Suret, Paris, V. Giard \& E. Brière, 1910, p. 1): "La question de l'incidence de l'impôt est un des sujets les plus negligés, en même temps qu'il est l'un des plus compliqués, de la science économique. A vrai dire, beaucoup d'écrivais l'ont traité, mais discusión de ce problème, dans lês livres scientifiques aussi bien que dans la vie journalière, a été souvent marquée par ce que de Pariru appelle $<<$ la simplicité de l'ignorance $>>$. 
constantes, crescentes ou decrescentes...), ${ }^{26}$ podendo ocorrer até mesmo em consequência da "percussão" 27 dos denominados "impostos diretos".

Rubens Gomes de Souza confirmou essa falácia em se atribuir aos impostos ditos indiretos o fenômeno da repercussão econômica, aduzindo que "este não é privativo deles [dos tributos indiretos], podendo também ocorrer quanto ao[s] chamados impostos diretos; basta lembrar a possibilidade de transferência pelo mutuante ao mutuário, do impôsto de renda (geralmente dado como impôsto direto típico) incidente sôbre os juros de empréstimos". ${ }^{28}$

Sobre essa evidência, Alfredo Augusto Becker ${ }^{29}$ repugnava as considerações em torno da repercussão econômica resumindo-a com um termo divulgado por Seligman: ${ }^{30}$ "simplicité de l'ignorance".

Sinteticamente, a "simplicidade da ignorância" manifesta-se pela aceitação das teorias, segundo as quais, $(i)$ o tributo indireto repercute; (ii) por sua própria natureza alguns tributos repercutem e outros não; (iii) o acréscimo de preço denota a repercussão econômica do tributo; (iv) o exame da escrita comercial do produtor ou comerciante demonstrará se houve ou não a repercussão; e $(v)$ a intenção do legislador prova a repercussão, ao outorgar ao contribuinte de iure o direito de reembolso ou retenção na fonte do valor devido a título de imposto.

Alfredo Augusto Becker impugnava, aduzindo que (i) a classificação dos tributos segundo o critério da repercussão econômica, embora considerada óbvia para discriminar tributos em diretos e indiretos, não tem fundamento científico, nem é praticável, devendo ser abolida nos planos técnico, administrativo e jurídico; ${ }^{31}$ ( $\mathrm{ii}$ ) a inferência de que

26 “1. L'objet est-il durable ou périssable? 2. L'objet est-il soumis a la loi du monopole ou a loi de la concorrence? 3. L'impôst est-il géneral ou exclusif? 4. Ya-t-il mobilité com plète du capital? 5. La demand de l'objet est-elle elastique? 6. Dans quelle mesure les avantages différentiels de la production affectent-ils l'offre? 7. L'objet est-il produit suivant les lois de coût constant, du coût croissant ou du coût décrois sant? 8. L'impôt est-il établi sur la marge ou sur l'éxcédent? 9. L'impôt est-il ou non eleve? 10. L'impôt est-il um bien final ou seulement um bien internédiaire?" (EDWIN R. A. SELIGMAN, Théorie de la Répercussin cit., p. 297).

27 "Percussão" ou "impacto" designa o primeiro momento do processo de repercussão econômica, identificado com a incidência jurídica do tributo. Cf. ALIOMAR BALEEIRO, Uma Introdução à Ciência cit., p. 154.

28 Nota de rodapé n. 4 ao artigo "Restituição de Impostos Indiretos", in Revista de Direito Administrativo, v. 21, Julho-Setembro de 1950, p. 25 [interpolamos]. Cf. LUIS EDUARDO SCHOUERI, Direito Tributário, São Paulo: Saraiva, 2011, p. 54 a 57; BRANDÃO MACHADO, "Repetição do Indébito Tributário", in Direito Tributário - Estudos em homenagem ao Prof. Ruy Barbosa Nogueira, Coord. Brandão Machado, São Paulo, Saraiva, 1984, p. 59 a 106; GASTON JĖZE, Cours Elémentaire de Science dês Finances et de Législation Financière Française, Paris, 5. ${ }^{a}$ èd., 1912, p. 782, apud Aliomar Baleeiro, Uma Introdução à Ciência cit., p. 264; ALFREDO AUGUSTO BECKER, Teoria Geral cit., p. 539, nota de rodapé n. 6; EDUARDO DOMINGOS BOTTALLO, "Restituição de Impostos Indiretos", in Revista de Direito Público n. 22, Caderno de Direito Tributário, p. 317.

29 Cf. Teoria Geral cit., p. 540 a 543.

30 Cf. nota 26, supra.

31 Infelizmente, Alfredo Augusto Becker deixa de explicitar porque o critério da repercussão econômica "deve 
alguns tributos repercutem por sua natureza, não resiste à singela verificação de que todos os tributos (inclusive aqueles denominados diretos) podem repercutir; (iii) o acréscimo do tributo na formação de preços e (iv) a questão do exame da escrita comercial, conforme estudos da teoria econômica, não permite verificar a repercussão econômica da imposição tributária, pois "o que o vendedor paga ao Estado, em última análise, de cada imposto, só por causalidade guarda relação com o montante calculado pela soma das parcelas que em tal conceito figuram nas faturas. Além disso, necessitaria saber-se qual seria o 'preço' cotizado separadamente do imposto na ausência deste, e isto não é um fato observável". ${ }^{32}$ Por último, $(v)$ a outorga, pelo legislador, de direito de reembolso ou retenção na fonte de valores devidos a título de tributo ao contribuinte de iure não prova a repercussão econômica, mas, sim, a repercussão jurídica da imposição tributária: o fenômeno da translação não se daria em razão de fenômeno econômico, mas por imposição legal que atribui, de modo expresso, o suporte da "carga tributária" a terceira pessoa não vinculada ao fato jurídico tributário. ${ }^{33}$

ser abolido no tríplice plano: técnico, administrativo e jurídico". Assim, devemos recuperar a fonte de sua afirmativa, que se encontra no célebre artigo de H. LAUFENBURGER ("La Distinzione", in Rivista di Diritto Finanziario cit.), que assim sintetizou a justificativa pela referida "abolição": "Dal punto di vista tecnico, per caratterizzare um'imposta diretta, si è messo l'accento sul modo di accertamento e di riscossione; sul piano amministrativo si è cercato di qualificare le imposte secondo gli unffici competenti; ed infinite sotto il profilo contenzioso, il carattere direto od indiretto dipende dalla giurisdizione competente, amministrativa o giudiziaria. Sotto tutti questi aspetti, l'evoluzione della struttura del sistema fiscale e della sua applicazione pratica ha abolito le barriere, cancellato le frontiere" (p. 6-7). No plano técnico, essa distinção é deveras artificial e ilusória, conforme exemplifica H. LAUFENBURGER: "La legge del 6 gennaio 1948 regola sotto la rubrica $<<$ imposte indirette $>>$ (artt. 17 e 18) il regime della $<<$ tassa $>>$ (vera imposta) sulle produzioni lattiere e della $<<$ tassa $>>$ speciale sulla cifra degli affari, il cui testo fondamentale era contenuto nel $<<$ Códice generale delle imposte dirette $>>$ allora vigente. Poichè la línea di separazzione tecnica fra tributti $<<$ diretti $>>$ ed $<<$ indiretti $>>$ è divenutta incerta, conviene colmare il distacco, che dal punto di vista amministrativo separa ancora, assai artificialmente, è vero, le due categorie di tributi” (p. 7-8). Da mesma forma não resiste essa distinção dos tributos no plano administrativo, porquanto "affermare che sonno dirette le imposte di competenza dell'amministrazione dei tributi diretti ed indirette quelle che vanno all'amministrazione dei tributi indiretti è evidentemente un'eresia, data l'estrema frequenza delle modifiche dell'organizzazione dei servizi amministrativi” (p. 8). No plano jurídico, improcede pela mesma razão: "la ripartizione del contenzioso fiscale non corrisponde piu alla divisione tradizionale fra imposte dirette ed indirette. [...] Questa distinzione crolla del tutto quando si consideri il problema del fondamento e del comportamento econômico dell'imposta" (p. 10 e 11).

32 E. ROLPH, Teoria de la Economía Fiscal, Madrid, 1958, trad. de The Theory of Fiscal Economies, California, 1954, p. 9, apud Alfredo Augusto Becker, Teoria Geral cit., p. 541.

33 “Com relação ao antigo imposto geral sobre receita (imposta generale sull'entrata), substituído na reforma tributária pelo imposto sobre o valor acrescido, tanto a administração pública como os tribunais italianos adotaram orientação ditada pela natureza do instituto jurídico denominado risalva, na linguagem da lei, e que consiste no reembolso do imposto que o chamado contribuinte de fato há de fazer ao sujeito passivo da obrigação. O art. 6 da lei que disciplinava o imposto (Lei n. 762, de 9-6-1940), ao indicar o contribuinte formal do tributo, dava-lhe o direito de reembolsar-se do respectivo valor da pessoa com quem contratasse o negócio de que resultava a receita, estabelecendo a lei, no mesmo artigo, que, para o exercício desse direito de reembolso, o contribuinte gozava dos mesmos privilégios que cabiam ao Estado para a cobrança de sua dívida ativa. Um especialista chamou a esse fenômeno translação jurídica, para diferenciá-lo da 
A classificação jurídica dos tributos não pode ser empreendida com dados da "Ciência" das Finanças, ${ }^{34}$ porque os critérios hábeis para uma classificação jurídica dos tributos devem levar em conta apenas dados juridicamente significativos, que tenham expressão jurídica, quer sejam em princípios gerais de direito ou no próprio direito positivo, objeto da Ciência Jurídica.

Por conseguinte, critérios pré-jurídicos não permitem e viabilizam a aplicação de normas jurídicas: ${ }^{35}$ a repercussão, constituindo-se em fenômeno essencialmente econômico, não pertence ao mundo normativo-jurídico, logo não se presta para atribuir qualquer consequência jurídica ao contribuinte de fato, figura essa conceitualmente ligada à ideia da translação econômica da imposição tributária.

Com efeito, é absurdo se conceber que do direito positivo ou da Ciência do Direito se possa tirar lições de Economia, de igual sorte, é equivocada a posição de que a Ciência Econômica pode colaborar com a interpretação do direito positivo, porque são duas camadas de linguagem, dois mundos inteiros e diferentes: "o direito positivo não pode ser concebido como o resultado de um processo de tradução, pois do 'ser' não se deduz o 'dever-ser' e vice-versa". 36

repercussão (Rosario Pisano, Imposta Generale Entrata, Milão, 1966, p. 184). Observa Berliri que a risalva não deve ser confundida de nenhum modo com a translação do imposto. Este é um fenômeno econômico que ocorre quando quem pagou um imposto (contribuinte percutido) logra, mediante o aumento do preço de um bem ou de um serviço, transferir no todo ou em parte a um terceiro (contribuinte incidido) o ônus do imposto; a risalva é um instituto jurídico por efeito do qual quem pagou o imposto (contribuinte de direito, segundo uma terminologia largamente utilizada em tema de imposto geral sobre receita) tem direito de exigir o reembolso do imposto a terceiro (contribuinte de fato), independentemente do fato de o terceiro estar, ou não, obrigado a pagar-lhe também um preço a outro título (Corso, cit., 1965, p. 185)" (BRANDÃO MACHADO, "Repetição do Indébito Tributário", in Direito Tributário - Estudos em homenagem ao Prof. Ruy Barbosa Nogueira cit., p. 94). Cf. GILBERTO DE ULHOA CANTO, Temas de Direito Tributário, v. 2. Rio de Janeiro, Alba, s/d, p. 151 a 155.

34 "A nosso ver, data maxima venia dos que pensem em contrário, uma tal classificação econômica não encontra correspondência com pressupostos básicos do sistema constitucional tributário vigente. Não vislumbramos, em nenhuma disposição da Constituição, qualquer norma jurídica que permita classificar os tributos por ela autorizados em diretos e indiretos, classificação esta que, portanto, é estranha ao sistema do direito positivo brasileiro, imprestável para ser aplicada à disciplina do regime jurídico da restituição do indébito tributário" (JOSÉ ARTUR LIMA GONÇALVES e MARCIO SEVERO MARQUES, “O Direito à Restituição do Indébito Tributário”, in Repetição do indébito e Compensação no Direito Tributário, Coord. H. Brito Machado, São Paulo-Fortaleza, Dialética-ICET, 1999, p. 227).

35 "Quando se depara com um sistema jurídico qualquer, seja ele qual for, não se pode tentar introduzir, no mundo jurídico, ingredientes que promanam no mundo natural, a menos que tenham sido encapados pelo sistema jurídico, porque aí estarão desessencializados, ganhando uma outra dimensão: a jurídica. É, portanto, o que ocorre no fenômeno da interpretação econômica do Direito Tributário. Se a norma jurídica não acolheu, não deu relevância a certos fatores de ordem econômica, estes pertencerão a um outro plano de relações e não ao plano normativo; não hão de ser indagados, salvo quando absorvidos pelo próprio sistema" (CELSO ANTONIO BANDEIRA DE MELLO, "Introdução", in Elementos de Direito Tributário - notas taquigráficas do III Curso de Especialização em Direito Tributário, realizado na Pontifícia Universidade Católica de São Paulo, Coord. G. Ataliba. São Paulo, Revista dos Tribunais, 1978, p. 8 e 9 ).

36 GUILHERME ADOLFO MENDES, "Direito e Tradução", in Vilém Flusser e Juristas - Comemoração dos 
Assim, não obstante o divórcio existente entre seus respectivos objetos, a ciência natural e a ciência jurídica estão em planos inconfundíveis ${ }^{37}$ pelos seus princípios lógicos: o físico deve descrever o fenômeno da gravidade pela lógica da consequência (porque se alguém atira um corpo no espaço, de maneira inelutável, inexorável, ele será atraído pela gravidade; isto é, há uma relação de causa e efeito); a aplicação do direito positivo, de maneira diversa, não é objeto de demonstração, mas de justificação. A decisão jurídica é guiada, portanto, não pela lógica da consequência, mas pela lógica da preferência das possibilidades, informada pela ciência do direito, para o atendimento às exigências da decidibilidade de conflitos e da segurança jurídica. ${ }^{38}$

\section{Imunidade tributária e tributos indiretos}

\subsection{Realização de Direitos Sociais e Ausência de Capacidade Contributiva}

Em um contexto histórico em que os Estados Modernos são incapazes de atender as demandas públicas a contento, a imunidade tributária das entidades de assistência social é justificada em face dos nobres e elevados fins de tais entidades que tomam para si certas atribuições que, em princípio, seriam de responsabilidade típica do Estado. $^{39}$

25 Anos do Grupo de Estudos cit., p. 225 e 226. "Quem é dotado de prudência sabe que assim como não deve o sapateiro ir além dos sapatos, não apenas não devem os apedeutas em medicinas e engenharias arriscarse na manipulação de bisturis e de réguas de cálculo, mas, também, os que não são dotados de formação jurídica, meter-se a 'interpretar' o direito e a discutir as leis. Se aqui não há mortes, há seguramente penas, quando a estulice leva o incauto a cruzar as linhas do ilícito e da ilegalidade. Apedeutas bem-intencionados recorrem a advogados e, nas complexidades, a juristas" (EROS ROBERTO GRAU, "Pareceres, Juristas e Apedeutas", in Revista dos Tribunais, v. 777, p. 37).

37 "Os institutos e categorias jurídicas só são válidos e operantes nos quadrantes do direito. Daí o terrível engano dos que pensam que a economia e o direito podem estudar um mesmo objeto, o tributo, por exemplo, intercambiando informações, observações, princípios e técnicas de compreensão, operação e aplicação. O conceito de tributo, para o direito, nasce e esgota-se no universo jurídico" (GERALDO ATALIBA, Hipótese de Incidência cit., p. 24).

38 Cf. FÁBIO KONDER COMPARATO, "Reflexões sobre o Método do Ensino Jurídico", in Revista da Faculdade de Direito da Universidade de São Paulo, v. LXXIV - em comemoração do jubileu de cátedra do Professor Dr. Goffredo da Silva Telles Júnior. São Paulo, 1979, p. 127; FERNANDO HERREN AGUILlAR, Metodologia da Ciência do Direito, 2. ed., São Paulo: Max Limonad. 1999, p. 64); EROS ROBERTO GRAU, O Direito Posto e o Direito Pressuposto, 3. ed., São Paulo: Malheiros, 2000, p. 32 a 34; "Interpretação da Lei Tributária e Segurança Jurídica", Conferência ao XXIV Congresso de Direito Tributário - IDEPE, em 22.10.2010, in Revista de Direito Tributário, v. 113, p. 220.

39 “Adiantamos que instituição de assistência social é a pessoa jurídica que secunda a atividade do Estado, buscando, sem finalidade lucrativa, atender aos direitos sociais tais como enumerados no art. $6^{\circ}$ da CF [...]. Infelizmente, o Estado não tem condições de, sozinho, prestar os serviços quem implementariam a fruição de todos estes direitos sociais. Daí precisa valer-se de entidades não-governamentais, com finalidades de assistência social beneficente. Tais entidades são justamente as instituições de assistência social sem fins lucrativos" (ROQUE ANTONIO CARRAZZA, Curso de Direito Constitucional Tributário, 27. ed., São Paulo: Malheiros, 2011, p. 852 e 853). Cf. BETINA TREIGER GRUPENMACHER, Eficácia e 
No Brasil, a relevância de tais entidades foi reconhecida sob a vigência do Estado Novo, presidido por Getúlio Vargas, que, promulgando a Constituição Federal de 1934, contemplou expressamente "isenção" para os estabelecimentos particulares de educação idôneos (art. 154) $)^{40}$ - estendendo-se a declaração de utilidade pública para as outras entidades por força da Lei Federal n. 91, de 1935, vigente até a presente data prevendo-se, literalmente, a "imunidade" para as entidades de assistência social, templos de qualquer culto e partidos políticos na Constituição Federal de 1946 (art. 31, inc. V, alínea “b”), sendo reiterada na Emenda Constitucional n. 18, de 1965 (art. 2º inc. IV, alínea “c”) - com a superveniência do Código Tributário Nacional (Lei n. 5.172, de 25.10.1966), cujo art. 14 prescreve as condições que tais entidades devem preencher para o gozo da desoneração tributária -, culminando-se com a Constituição da República de 1988, que inseriu como condição para o gozo da "imunidade" a ausência de finalidade lucrativa ${ }^{41}$

Aplicabilidade das Limitações Constitucionais ao Poder de Tributar, São Paulo: Resenha Tributária, 1997, p. 136.

Embora extrapole o corte metodológico do tema do presente trabalho, é pertinente a reflexão do Professor SILVIO LUIS FERREIRA DA ROCHA que pondera criticamente a "Reforma do Estado" levada a efeito pelos governos dos Presidentes Fernando Collor de Mello e Fernando Henrique Cardoso, concluíndo que as organizações sociais não podem "substituir" o Estado no exercício da sua competência, sobretudo, nas áreas de educação e saúde, porque a participação de terceiros em funções típicas de Estado é "complementar" (princípio da subsidiariedade), não é de "substituição" (Terceiro Setor, 2. ed., São Paulo: Malheiros, 2006, p. 19-21, 38-41). Posturas ideológicas a respeito podem ser conferidas entre CARLOS ARI SUNDFELD (Direito Administrativo para Céticos, São Paulo: Malheiros, 2012, p. 127-131) e CELSO ANTONIO BANDEIRA DE MELLO ("O Neocolonialismo e o Direito Administrativo Brasileiro", in Curso de Direito Administrativo, 29. ed., São Paulo: Malheiros, 2012, p. 1083-1097).

40 Tal como ocorre na redação do vigente art. $195, \S 7^{\circ}$ da Constituição da República de 1988, a expressão "isenção" deve ser lida como "imunidade", porque, tal como assevera o JOSÉ SOUTO MAIOR BORGES, "é a imunidade ontologicamente constitucional. Nisto, distingue-se da isenção, que está sob reserva de lei. [...] Porque não distinguiu conceitualmente a imunidade da isenção, incorreu Bilac Pinto no equívoco de admitir isenções em texto constitucional, na sua monografia sobre o instituto da contribuição de melhoria" (Teoria Geral da Isenção Tributária, 3. ed., São Paulo: Malheiros, 2007, p. 219/220). Em sua tese de doutorado defendida e aprovada perante a Faculdade de Direito da Pontifícia Universidade Católica de São Paulo, REGINA HELENA COSTA define a imunidade tributária como "exoneração, fixada constitucionalmente" (Imunidades Tributárias - Teoria e Análise da Jurisprudência do STF, 2. ed., São Paulo: Malheiros, 2006, p. 52). Cf. SACHA CALMON NAVARRO COELHO, "Imunidade Tributária", in Revista de Direito Tributário, v. 38, p. 247. Evitando-se desnecessária tautologia, confira-se os esclarecimentos do Professor PAULO DE BARROS CARVALHO: "o preceito de imunidade exerce função de colaborar, de forma especial, no desenho das competências impositivas. São normas constitucionais. Não cuidam da problemática da incidência, atuando em instante que antecede, na lógica do sistema, o momento da percussão tributária. Já a isenção se dá no plano da legislação ordinária" (Direito Tributário, Linguagem e Método, 2. ed., São Paulo: Noeses, 2009, p. 347).

41 "Mais que entidade de assistência social, tem ela que ser beneficente. Esse vocábulo tem por fim deixar patente que a instituição deve assistir carentes e necessitados, provendo uma ou algumas de suas (destes) necessidades (assistência médica, odontológica, jurídica). Ter atuação que visa a proteção da família ou amparo à velhice, a crianças e adolescentes carentes. Colaborar com o Estado em outros campos, seja promovendo a integração de pessoas ao mercado de trabalho, seja viabilizando a habilitação e reabilitação das pessoas portadoras de deficiência, seja proporcionando sua integração à vida comunitária" (AIRES F. BARRETO e PAULO A. BARRETO, Imunidades Tributárias: Limitações Constitucionais ao Poder 
(art. 150, inc. VI, alínea "c") e incluiu "isenção" de tais entidades às contribuições sociais (art. 195 , par. $\left.7^{\circ}\right) .{ }^{42}$

A "imunidade tributária" é outorgada às entidades de assistência social"3 visando facilitar a atuação longa manus do Poder Público por tais instituições na substituição de áreas deficientes de atuação estatal, para alcançar os efeitos de preservação, proteção e estímulo, inspiradores do Poder Constituinte. ${ }^{44}$

É cediço que toda outorga de competência aos entes públicos tem um sentido positivo e outro, negativo. ${ }^{45}$ Positivo, no caso, na medida em que permite criar exações quando outorgado poder de tributar. E negativo, porque a outorga de competência integra o estatuto dos cidadãos, que tem o direito de não se sujeitar para além do que o Poder Público está constitucionalmente autorizado. ${ }^{46}$

de Tributar, 2. ed., São Paulo: Dialética, 2007, p. 108). Outra distinção possível é a seguinte: "Entidade beneficente não possui finalidade lucrativa, mas, além disso, é aquela que dedica suas atividades, ainda que parcialmente, ao atendimento gratuito dos necessitados. A gratuidade dos serviços prestados é, portanto, elemento caracterizador da beneficência" (REGINA HELENA COSTA, Imunidades Tributárias cit., p. 184).

42 Cf. ADRIANA MARUBAYASHI ANGELOZZI, A Imunidade Tributária das Instituições de Assistência Social, Dissertação de Mestrado orientada pela Prof. Dra. Elisabeth Nazar Carrazza, perante a Faculdade de Direito da Pontifícia Universidade Católica de São Paulo, aprovada em 2005, p. 9 a 18; REGINA HELENA COSTA, Imunidades Tributárias cit., p. 25 a 27; GYORDANO KELTON ALVES LUZ, Teoria da Norma Tributária Imunizante, Dissertação de Mestrado orientada pela Prof. Dra. Fabiana Del Padre Tomé, perante a Faculdade de Direito da Pontifícia Universidade Católica de São Paulo, aprovada em 2010, p. 87 a 89.

43 "Ressaltamos que as imunidades tributárias beneficiam, em última análise, pessoas. É certo que a doutrina mais tradicional classifica as imunidades em subjetivas, objetivas e mistas, conforme alcançarem pessoas, coisas ou ambas. Pensamos que esta classificação é útil e até a empregamos mais adiante. Todavia, parecenos que, em termos rigorosamente técnicos, a imunidade é sempre subjetiva, já que, invariavelmente, beneficia pessoas, quer por sua natureza jurídica, quer pelas relações que guardam com determinados fatos, bens ou situações" (ROQUE ANTONIO CARRAZZA, Curso de Direito Constitucional Tributário cit., p. 774).

44 "A Constituição quer imunes instituições desinteressadas e nascidas do espírito de cooperação com os poderes públicos, em suas atividades específicas” (ALIOMAR BALEEIRO, Direito Tributário Brasileiro cit., p. 177).

45 "A lei constitucional, instrumento primeiro e soberano, que se sobrepõe aos demais veículos introdutórios de normas. [...] É na Lei das Leis que estão consignadas as permissões para os legislativos da União, dos Estados e dos Municípios instituírem seus tributos, como também é lá que estão fixados os limites positivos e negativos da atividade legiferante daquelas pessoas" (PAULO DE BARROS CARVALHO, Curso de Direito Tributário, 22. ed., São Paulo: Saraiva, 2010, p. 91).

46 "O Estado não desfruta do poder, na condição de dono ou senhor, mas como representante do titular, que é o povo. Os particulares, embora sofram o poder, não são mero objeto dele. É intuitivo, destarte, que as relações jurídicas entre Estado e indivíduo, conquanto marcadas pelo signo da autoridade - visto estar em causa o exercício do poder político -, não se processa sob o império da submissão. Ainda porque o indivíduo, mesmo em suas relações com o Estado, apresenta-se sujeito livre, munido de direitos" (CARLOS ARI SUNDFELD, Fundamentos de Direito Público, 4. ed., São Paulo: Malheiros, 2003, p. 109-110). Cf. AGUSTIN GORDILlO, Princípios Gerais de Direito Público, trad. port. M. A. Greco. São Paulo: Revista dos Tribunais, 1977, p. 68-69. 
Em que pese as disputas doutrinárias ${ }^{47}$ para conceituá-la, ${ }^{48}$ a "imunidade tributária" das entidades assistenciais é concebida para que seja ( $i$ ) respeitada a ausência de capacidade contributiva, mormente porque não possuem finalidade lucrativa; e seja ( $i$ ) realizado valor constitucionalmente relevante de serem atendidos por tais entidades os direitos sociais dos hipossuficientes. Qualquer imposto que sobre elas incidisse implicaria desfalcar o patrimônio, diminuir a eficácia dos serviços ou a integral aplicação das rendas aos objetivos específicos dessas entidades presumidamente desinteressadas por sua própria natureza. ${ }^{49}$

47 "Os argumentos de autoridade tem pouca importância - as 'autoridades' cometeram erros no passado. Voltarão a cometê-los no futuro. Uma forma melhor de expressar essa idéia é, talvez dizer, que na ciência não existem autoridades; quando muito, há especialistas" (CARL SAGAN, "A Arte Refinada de Detectar Mentiras", in O Mundo Assombrado pelos Demônios: a ciência vista como uma vela no escuro, trad. port. R. Eichemberg, São Paulo: Cia. das Letras, 2006, p. 241).

Já no século XVIII, a insegura aferição da comunis doctorum opinio serviu para ordernar prejudiciais cavilações, semeando-se dúvidas por frívolos pretextos tirados de extravagantes sutilezas da caótica legislação, ensejando a Lei da Boa Razão, de 18 de Agosto de 1769, e a Reforma dos Estatutos da Universidade de Coimbra (1772): "Por esse motivo é necessária a História, para vermos se devem entender e tomar as coisas; e por este mesmo motivo, não devemos fazer caso do que disseram muitos intérpretes (...) estes homens [os doutores do direito comum (glosadores e comentadores)] daquele tempo eram venerados, mas para dizer a verdade, eram, ainda que doutos, ignorantes de antiguidades. [...] Um levantou uma doutrina nova, ou por capricho, ou por necessitar dela para alguma escritura. Os discípulos abraçaram-na. Algum advogado serviu-se dela para outro caso. E desta sorte, citando uns a outros, se fez comum. Apareceu outro advogado, a quem não agradava. Impugnou-a. Teve sequazes. E temos outra opinião comum contrária. E dessa sorte apareceram tantas opiniões comuns, contrárias entre si, que é uma piedade. [...] Enfim, isto chegou a termos que hoje não se sabe qual é a opinião comum" (LUIS ANTONIO VERNEY, Verdadeiro Método de Estudar II - Estudos Literários, Lisboa, Livraria Sá da Costa Editora, 1950, p. 170, 158-159, 186-192, apud ESTEVAN LO RÉ POUSADA, Aspectos de Uma Tradição Jurídica Romano-Peninsular: Delineamentos sobre a História do Mandato no Direito Luso-Brasileiro, tese de doutorado em Direito Civil, Faculdade de Direito da Universidade de São Paulo, 2010, p. 238).

48 "Para Bernardo de Moraes, por exemplo, elas são hipóteses constitucionais de não incidência. Segundo Ruy Barbosa Nogueira, trata-se de forma de exclusão do poder de tributar. Neste sentido, também sustentam Aires F. Barreto e Paulo A. Barreto [...]. Por seu turno, Amilcar de Araújo Falcão defende que a imunidade é forma de supressão da competência tributária impositiva. No entender de Pontes de Miranda e José Souto Maior Borges, trata-se de balisa constitucionalmente [sic] posta pela Constituição [sic] ao exercício da competência tributária. Aos olhos de Luis Eduardo Schoueri, as imunidades consubstanciam regras constitucionais que excluem, da competência tributária, uma determinada realidade. Para Regina Helena Costa, as imunidades tributárias podem ser, ainda, tomadas como princípio constitucional, ou como categoria referida a circunstâncias extrajurídicas. No entender de Sacha Calmon Navarro Coelho, as imunidades são técnicas legislativas de exoneração do tributo [...]. Para Paulo de Barros Carvalho, a imunidade é norma jurídica que colabora, juntamente com outras, na demarcação (negativa) da competência tributária dos entes políticos, mediante um esquema sintático proibitivo ou vedatório. Para ele, todas as regras constitucionais, por si só, já revelam uma limitação ao poder de tributar, inclusive a outorga de competência tributária, já que demarca e delimita rigidamente o poder estatal de tributar [...]. Em sentido semelhante, ensina Carrazza" (LUIS GUSTAVO SANTANA DE CARVALHO, "O Alcance da Norma Jurídica Constitucional Tributária que Imuniza o Livro", in Revista de Direito Tributário, v. 114, p. 122 e 123).

49 "Quando uma entidade privada assume tais tarefas, desincumbe o Estado de executá-las. Exerce, pois, atividade de Estado. Atua, assim, no setor público, em que não cabe cogitar de capacidade contributiva" (LUIS EDUARDO SCHOUERI, Direito Tributário, São Paulo: Saraiva, 2011, p. 393). 
Pretendendo-se maximizar os efeitos da imunidade tributária, algumas entidades de assistência social sustentam a tese segundo a qual a desoneração tributária deve alcançar situações em que são tidas como contribuintes "de fato" de impostos incidentes sobre operações contratadas com seus fornecedores, sujeitos passivos "de direito".

Este, enfim, é o nosso objeto de análise: a questão é saber se há imunidade a impostos se o vendedor não é imune, mas o comprador é entidade de assistência social imune a impostos por força do art. 150, inciso VI, alínea "c" da Constituição da República.

\section{2. - Consideração Econômica e Reconhecimento do Contribuinte "de Fato"}

Sob as premissas da Ciência das Finanças, Ruy Barbosa Nogueira consignou em parecer que, "quando o Constituinte outorga e garante às citadas entidades imunidade contra certos e determinados impostos é porque estes desfalcariam seu patrimônio, sua renda ou oneraria seus serviços humanitários ou institucionais. Tanto é assim que, quando impostos indiretos possam, com seu ônus, desfalcar estamentos imunes, isto é, quando seu encargo financeiro as atingir como utentes, importadoras para uso próprio ou como consumidoras finais, também ficam imunes em relação a esses possíveis desfalques". ${ }^{50}$

Não se trata de entendimento vetusto e isolado, colhendo-se a adesão de Luciano Amaro, para quem "por mais que o jurista repugne a noção de impostos indiretos, não temos como evitá-los, por uma razão muito simples: eles existem. E quem demonstra capacidade contributiva não é necessariamente a pessoa que a lei escolhe para figurar como contribuinte. [...] A capacidade econômica do consumidor é que precisa ser ponderada para efeito da definição do eventual ônus fiscal (pois ele será o 'contribuinte de fato')". ${ }^{51}$

Regina Helena Costa $^{52}$ e Mizabel Abreu Machado Derzi, ${ }^{53}$ ao endossarem essa tese, agregam o argumento de que há repertório jurídico (e não simplesmente econômico) que sinaliza preocupação com o contribuinte "de fato" ou consumidor final ao se verificar que $(i)$ a própria Constituição da República imprime noção da "capacidade contributiva" aos impostos ditos "indiretos" ao prever as regras da "não-cumulatividade" e da "seletividade de alíquotas" com vistas à sua não-oneração excessiva, tendo (ii) o legislador infraconstitucional reconhecido a juridicidade do fenômeno da "repercussão

50 "Impostos Diretos e Indiretos, Entidades Sem Fim Lucrativo", in Imunidades - Contra Impostos na Constituição Anterior e Sua Disciplina Mais Completa na Constituição de 1988, 2. ed., São Paulo: Saraiva, 1992, p. 25.

51 Direito Tributário Brasileiro cit., p. 327.

52 Imunidades Tributárias cit., p. 149.

53 "A Imunidade Recíproca, o Princípio Federal e a Emenda Constitucional n. 3, de 1993", in Revista de Direito Tributário, v. 62, p. 96 e 97. 
econômica" do tributo e da figura do contribuinte "de fato" ao prever o art. 166 do Código Tributário Nacional e tendo o Supremo Tribunal Federal referendado a existência do contribuinte "de fato" com a edição da Súmula n. 546. ${ }^{54}$

Em contraposição, temos que considerar que a realidade não passa de uma interpretação $\mathrm{o}^{55} \mathrm{e}$ "o oposto de uma verdade profunda não é um erro, mas outra verdade profunda" (Niels Bohr).

Em coerência às nossas premissas de que não existe verificabilidade segura do fenômeno da "repercussão econômica dos tributos", ${ }^{56}$ concordamos com a veemência de Alcides Jorge Costa, segundo a qual "a capacidade contributiva a considerar é a do sujeito passivo de direito, sem considerar o fenômeno da repercussão. Sabe-se que praticamente todos os impostos são repercutíveis, uns mais, outros menos, e que a repercussão é

54 REGINA HELENA COSTA, Imunidades Tributárias cit., p. 243 e 244.

55 Cf. VILÉM FLUSSER, Lingua e Realidade, 3. ed., São Paulo: Annablume, 2004, p. 45; GREGÓRIO ROBLES, O Direito como Texto: Quatro Estudos de Teoria Comunicacional do Direito, Barueri: Manole, 2005, p. XII; FABIANA DEL PADRÉ TOMÉ, A Prova no Direito Tributário, 3. ed., São Paulo: Noeses, 2011/2012, p. 1-39; PAULO DE BARROS CARVALHO, "O Objeto da Ciência do Direito e o Papel do Jurista: Relações de Derivação e Positivação no Sistema Comunicacional do Direito", in Tributação e Desenvolvimento: Homenagem ao Professor Aires Barreto, coord. Eurico Marcos Diniz de Santi, São Paulo: Quartier Latin, 2011, p. 547-564; EURICO MARCOS DINIZ DE SANTI, "Apresentação", in Curso de Direito Tributário e Finanças Públicas - Do Fato à Norma, da Realidade ao Conceito Jurídico, São Paulo: Saraiva, 2008.

56 "Prof. Geraldo Ataliba - Somos discípulos do Prof. Aliomar Baleeiro. Reconhecemos que ele é um pioneiro, é um líder, um homem que começou a estudar direito tributário no Brasil e nos trouxe os primeiros conhecimentos de direito tributário e forma, ao lado de Bilac Pinto, Rubens Gomes de Souza e mais dois ou três só, uma equipe pioneira de valor extraordinário. Contamos com a vantagem de poder estudar direito tributário depois deles nos terem ensinado a dar os primeiros passos. Não podemos negar isso. Mas não nos sentimos obrigados, por causa dessa autoridade, a deixar de usar o nosso raciocínio e o nosso critério jurídico. Essa argumentação do Prof. Aliomar Baleeiro [distinguir taxas e impostos, segundo a destinação do dinheiro arrecadado] é perfeitamente correta, mas é uma argumentação de ciência das finanças, préjurídica, e que não importa num debate jurídico. Por quê? Porque o ponto de partida do jurista é a lei. O que ele tem que examinar é o texto legal, com critérios técnico-jurídicos e não com critérios empregados pelo legislador: econômicos, políticos, já peremptos depois de feita a lei. Assim, ou nos valemos de um critério jurídico, para reconhecer as espécies tributárias, ou vamos discutir aquilo que o legislador já discutiu e nunca chegar a resultado algum.

Pedimo-lhes que dêem o devido valor a Alfredo Becker, pela contribuição, que trouxe, com seu livro, cujo primeiro capítulo é 'Manicômio Jurídico', que insiste muito no que chama de reformulação da atitude mental do jurista. Precisamos reformular a atitude mental. Foi a razão pela qual pedimos ao Prof. Bandeira de Mello que hoje, sacrificando certos interesses seus, aqui estivesse presente. Porque o nosso maior problema é derrubar preconceitos e, sobretudo, reformular a nossa atitude, porque se nós fizermos um curso de pósgraduação, de especialização em direito tributário, para repetirmos aqui, acriticamente o que há por aí, não é preciso fazer curso. Continuaremos lendo o que vínhamos lendo. Tentemos conquistar posições próprias. Tomemos como premissa que é preciso ter um critério jurídico para estudar direito. E o critério jurídico é examinar hipóteses de incidência, quando se trata de fixar a natureza de um tributo" ("Hermenêutica e Sistema Constitucional Tributário", in Interpretação no Direito Tributário. Org. B. Ribeiro de Moraes, coord. G. Ataliba. São Paulo: EDUC, 1975, p. 54). 
fenômeno multifacetado, de difícil apreensão", ${ }^{57}$ cuja conclusão é compartilhada por Luis Eduardo Schoueri. ${ }^{58}$

As referências à "não cumulatividade" à "seletividade das alíquotas" não são pertinentes ao tema da "imunidade tributária", porque pressupõem que o tributo já foi instituído, situando-se, portanto, no contexto do exercício da competência tributária, ao contrário da "imunidade tributária", em que a competência impositiva já nasce tolhida em relação às pessoas protegidas por essa norma.

A referência à "não cumulatividade" não é pertinente ao tema da "imunidade tributária", porque o direito de abatimento de créditos não possui o condão de converter o ICMS em "imposto sobre valor agregado", 59 circunstância que poderia corroborar a tese de que a "não-cumulatividade" teria como inspiração o contribuinte "de fato".

Da mesma forma a "seletividade das alíquotas" dos impostos tidos como "indiretos" está fora do contexto das "imunidades tributárias" porque estas pressupõe a ausência de competência tributária que torna viável "manipular" seletivamente alíquotas.

Deveras, a "seletividade das alíquotas" não é pertinente para aferir "capacidade contributiva" do contribuinte "de fato", na medida em que a "extrafiscalidade"60 não é o fundamento jurídico da "imunidade tributária".

Com efeito, Luis Eduardo Schoueri conclui que a imunidade tributária às entidades de assistência social não contém qualquer norma indutora porque tais entes, limitando-se às suas finalidades essenciais, não estão no Domínio Econômico ${ }^{61}$ e Roque Antonio Carrazza explica que a "extrafiscalidade" do ICMS não guarda qualquer nexo com a "imunidade tributária", porque a "seletividade de alíquotas" varia apenas de acordo com a essencialidade do bem e não em virtude da etapa de circulação ou do destino ou do destinatário da mercadoria ou do serviço. ${ }^{62}$

57 "Capacidade Contributiva", in Revista de Direito Tributário, v. 55, p. 302.

58 Direito Tributário cit., p. 408.

59 "O ICMS não é um imposto sobre o valor agregado. Só para registro, o imposto sobre o valor agregado caracteriza-se, nos patamares do Direito, por incidir sobre a parcela acrescida, ou seja, sobre a diferença positiva de valor que se verifica entre duas operações em sequência, alcançando o novo contribuinte na justa proporção do que ele adicionou ao bem. Não é o caso do ICMS, que grava o valor total da operação.[...] Fosse o ICMS um tributo sobre o valor acrescido, havendo operação 'abaixo do custo', o contribuinte não precisaria debitar-se sobre o valor da saída, já que não estaria presente, no caso, o elemento quantificador do fato imponível, ou seja, a agregação do valor" (ROQUE ANTONIO CARRAZZA, ICMS, 11. ed., São Paulo: Malheiros, 2006, p. 310).

60 "Plano paralelo ao da fiscalidade é o da extrafiscalidade que consiste no "emprego dos instrumentos tributários com objetivos não fiscais, mas econômicos, ou seja, para finalidades não financeiras, mas regulatórias de comportamentos sociais em matéria econômica, social e política" (EDUARDO DOMINGOS BOTTALLO, Fundamentos do IPI, São Paulo: Revista dos Tribunais, 2002, p. 57).

${ }_{61}$ Normas Tributárias Indutoras e Intervenção Econômica, Rio de Janeiro: Forense, 2005, p. 316.

62 "A seletividade, no caso, deve levar em conta a natureza da mercadoria ou do serviço, Não sua destinação ou origem, que a isto obsta o art. 152 da CF. Também não podem interferir no assunto a fase do ciclo de produção ou as condições econômicas de quem adquire a mercadoria ou frui do serviço ” (ICMS cit., p. 376). 
Finalmente, não se pode interpretar a Constituição mediante remissão à lei, mas, pelo contrário, só a lei pode ser interpretada à luz da Constituição. Não é possível inverter essa ordem. ${ }^{63}$

Mesmo que se pudesse entender logicamente autorizada essa remissão à lei, sob o fundamento de que o art. 166 do CTN é reguladora do dispositivo Constitucional - e que foi (supostamente) referendada pela edição da Súmula STF 546 - ainda assim não se pode acolher os argumentos, porque em nenhum momento foi reconhecido pelo direito a figura do contribuinte "de fato", motivo pela qual entendemos que a imunidade tributária das entidades de assistência social não pode alcançar contingências em que essas entidades figurem como contribuintes "de fato" em relação aos seus fornecedores sob o pálio da "repercussão econômica" dos impostos.

É bem sabido que a Suprema Corte editou duas súmulas (Súmulas ns. 71 e 546). Analisemos a primeira, que é anterior à promulgação do Código Tributário Nacional.

ASúmula n. 71, de 16 de dezembro de 1963, enuncia o seguinte entendimento daquele Tribunal: "Embora pago indevidamente, não cabe restituição do tributo indireto".

Um exame superficial conduz o leitor meramente alfabetizado a deduzir simplesmente a impossibilidade de restituição de valores pagos indevidamente a título de "tributo indireto".

$\mathrm{O}$ rigoroso exame dos precedentes que embasaram aquele enunciado evidencia que, na falta de disposição legal específica para disciplinar a repetição de indébito tributário, a Súmula n. 71 do Supremo Tribunal Federal foi inspirada ( $i$ ) no princípio geral de direito segundo o qual "todo aquele que recebeu o que não lhe era devido fica obrigado a restituir", ${ }^{64}$ cujo desdobramento implica o reconhecimento jurídico do contribuinte "de

63 GERALDO ATALIBA, "Autarquias e Imposto do Selo (Diante da Emenda Constitucional n. 5)", Separata da Revista dos Tribunais, v. 344, jun.1964, p. 12.

64 "Nemo locupletari potest cum aliena iniuria", princípio positivado no direito positivo brasileiro no art. 876 do Código Civil, equivalente ao art. 964 do Código Civil de 1916, expressamente indicado pela Súmula n. 71 do Supremo Tribunal Federal e presente em todos os precedentes-paradigmas que a embasaram: "Bem ponderou o eminente Min. Vilas Boas que o fundamento da repetição do indébito, do mesmo modo que, na ação in rem verso, é a equidade, pois não seria razoável que alguém se locupletasse à custa do empobrecimento alheio. Em seu recente livro Obrigações, o Prof. Orlando Gomes assim se refere à ação de enriquecimento: 'A relação jurídica processual no enriquecimento sem causa tratava-se entre o enriquecido e o empobrecido. O autor da ação de in rem verso é aquele que sofreu o prejuízo; réu, o que, em seu detrimento, enriqueceu (p. 325)'. É essencial, portanto, que o autor, que reclama a restituição da quantia paga indevidamente, tenha sofrido prejuízo correspondente, isto é, tenha suportado equivalente desfalque no seu patrimônio./ Isto, evidentemente, não ocorreu nos autos. Perícia realizada na primeira instância comprovou que os impostos pagos pelo recorrente, e que este pretende reaver, forma carregados no preço das mercadorias vendidas a terceiros" (trecho do voto do Ministro Victor Nunes, proferido nos autos do recurso extraordinário n. 46.450-RS, 2. ${ }^{\text {a } T u r m a, ~ v o t a c ̧ a ̃ o ~ u n a ̂ n i m e, ~ j u l g a d o ~ e m ~ 31.05 .61, ~ a p u d ~}$ JOSÉ MORSCHBACHER, Repetição do indébito Tributário Indireto, São Paulo: Dialética, 1998, p. 90). Convém anotar a seguinte passagem do parecer de GILBERTO DE ULHÔA CANTO, "Natureza Tributária da Taxa de Despacho Aduaneiro - Restituição de imposto indireto pago indevidamente", in Revista de 
fato", porquanto é este que teria sofrido a efetiva diminuição patrimonial sem causa; isto porque (ii) partindo-se de premissas de Ciência das Finanças presume-se, nos casos de tributos "indiretos", que o contribuinte "de direito" transfere o encargo financeiro dos tributos por ele recolhidos no preço das mercadorias vendidas a terceiros. ${ }^{65}$

Sucede desse entendimento, outrossim, que na ausência de justo título que ampare o contribuinte de direito a pleitear a restituição do indébito tributário - fazendo prova negativa da repercussão, ou, no caso de ter transferido a terceiro, estar, pelo contribuinte de fato, expressamente autorizado para receber os valores indevidos - deve prevalecer o princípio da supremacia do interesse público, incorporando-se as quantias indevidamente recolhidas ao patrimônio do Estado, porquanto uma análise de ciência das finanças esclarece que esses valores constituirão a receita pública, presumivelmente, beneficiando o interesse coletivo, que deve ser prestigiado em detrimento da pretendida fruição pessoal do particular. ${ }^{66}$

Direito Público, n. 1, p. 109: "27. Em que se pese sua opinião agora, como integrante do Supremo Tribunal Federal, o Min. Vilas Boas, quando membro do Tribunal de Justiça de Minas Gerais, relatando a já citada Apelação n. 1.502 ('Rev. Forense', v. 93, p. 330) admitiu a restituição ao 'solvens' [contribuinte de direito] como simples e direta conseqüência de haver sido declarado inconstitucional imposto indireto por ele pago" [interpolamos]. Cf. JOSÉ ALFREDO DE OLIVEIRA BARACHO, "O Enriquecimento Injusto como Princípio Geral do Direito Administrativo", in Revista dos Tribunais, v. 755. São Paulo: Revista dos Tribunais, 1998, p. 11/75; CELSO ANTONIO BANDEIRA DE MELLO, "O Princípio do Enriquecimento sem Causa em Direito Administrativo", in Grandes Temas de Direito Administrativo, São Paulo: Malheiros, 2009 , p. 320.

65 Um dos precedentes-paradigmas da referida súmula, os embargos sobre recurso extraordinário n. 47.069SP, tem a seguinte ementa: "Incabível a repetição do imposto indireto, que repercute sobre terceiro, não se configurando o prejuízo do 'solvens' " (STF, Pleno, Rel. Min. Ary Franco, julgado em 27.04.62, votação unânime, apud JOSÉ MORSCHBACHER, Repetição do indébito cit., p. 91). Do voto do Ministro-Relator, extrai-se o seguinte entendimento, a ensejar a edição da Súmula n. 71: "A matéria é pacífica. Nós não damos repetição do indébito, porque se trata de imposto indireto. (...) Desde que se trata de imposto indireto, não há repetição do indébito" (Loc. cit., p. 93). Ressalta-se que nem sempre a Suprema Corte adotou esse posicionamento, sendo noticiados, por RUBENS GOMES DE SOUZA, dois antigos precedentes desse mesmo Tribunal que contrariam a adoção de premissas econômicas para a composição de lides tributárias em matéria de repetição de indébito, inferindo-se que a repercussão é um fenômeno tipicamente econômico e não jurídico, evidência esta suficiente para obstar qualquer consequência jurídica ao contribuinte de fato: nos recursos extraordinários ns. 2.051 e 7.122, extrai-se a tese de que o direito à restituição do indébito tributário compete ao contribuinte de direito, prescindindo-se da demonstração da inocorrência da repercussão a terceiro - contribuinte de fato (Cf. "Restituição de Impostos", in Revista de Direito Administrativo cit., p. 32 e 33). No mesmo sentido, GILBERTO DE ULHÔA CANTO relata, também, a antiga posição do Supremo Tribunal Federal, reconhecendo a legitimidade do contribuinte de direito, no parecer "Natureza Tributária da Taxa", in Revista de Direito Público cit., p. 98 a 114.

${ }_{66}$ Essa tese está expressa em um dos precedentes-paradigmas da Súmula n. 71, assim: "Nem se diga que, havendo a Fazenda Pública recebido o que não era devido, estava na obrigação de restituir, nos termos do art. 964 do CC [redação equivalente no art. 876 do Novo Código Civil]. Realmente, essa obrigação subsiste, mas não é credor dela o solvens que tenha transferido o imposto - e, portanto, o prejuízo aos consumidores. Falta-lhe, para isso, legitimidade ad causam. Seria menos justo proporcionar-lhe um sobrelucro sem causa, para seu proveito pessoal, do que deixar esse valor em poder do Estado, que, presumivelmente, já o terá aplicado na manutenção dos serviços públicos e na satisfação dos encargos diversos que oneram o Tesouro em benefício da coletividade. Se com a carência ou improcedência da ação, quer em favor do contribuinte, 
Certamente inspirada na solução jurisprudencial construída e sedimentada pelo Supremo Tribunal Federal, cujo cunho oficial imprime-lhe peso considerável na administração da justiça, a Comissão de Reforma Tributária de 1965 resolveu disciplinar o tema da repetição do indébito dos "tributos indiretos" seguindo a orientação pretoriana, já sumulada.

Logo vislumbraram, a doutrina e a jurisprudência, fundamento legal para a composição da controvérsia sobre o tema da repetição dos tributos indiretos no texto do art. 166 do Código Tributário Nacional (Lei n. 5.172, de 25 de outubro de 1966), cuja importância justifica a transcrição: "Art. 166. A restituição de tributos que comportem, por sua natureza, transferência do encargo financeiro somente será feita a quem prover haver assumido referido encargo, ou, no caso de tê-lo transferido a terceiro, estar por este expressamente autorizado a recebê-la."

A despeito de um pronunciamento expresso acerca da suposta inconstitucionalidade do art. 166 do Código Tributário Nacional, o Supremo Tribunal Federal editou a Súmula n. 546, ${ }^{67}$ em 3 de outubro de 1969: “Cabe a restituição do tributo

se for julgado procedente o pedido, não há que hesitar: impõe-se a primeira alternativa, pois o Estado representa, por definição, o interesse coletivo, a cuja promoção se destina, no conjunto da receita pública, a importância reclamada pelo particular, para sua fruição pessoal. Esta solução é a que corresponde à equidade, fundamento básico da ação proposta" (Trecho do voto do Ministro Victor Nunes, proferido nos autos do recurso extraordinário n. 46.450-RS, apud JOSÉ MORSCHBACHER, Repetição do indébito cit., p. 90 e 91) [interpolamos].

67 “Aluno - O STF editou uma súmula sobre o problema da repetição do indébito, onde decidiu que, se tratando de tributo indireto, não é possível essa restituição. A idéia de tributo indireto é um instituto jurídico ou econômico?

Prof. Geraldo Ataliba - Não tem nada de jurídico.

Aluno - Então, o STF decidiu com base num instituto de economia política. O STF errou?

Prof. Geraldo Ataliba - Errou.

Prof. Paulo de Barros Carvalho - O Supremo pode errar?

Prof. Geraldo Ataliba - A sua observação foi oportuna, pela seguinte razão, porque nos lembra que a finalidade do curso é estudar direito para ser melhor conhecido e, portanto, para ser melhor aplicado. Estamos estudando a Constituição. Logo, tudo o que estiver abaixo da Constituição - e o Supremo está abaixo da Constituição - pode não estar de acordo com a mesma, e estudando-a, teremos critérios seguros para saber o que é certo; poderemos até reconhecer lei complementar, lei ordinária ou decisões judiciárias, que estejam em contraste com as exigências constitucionais.

Há uma outra perspectiva, que é a perspectiva prática. Vamos lutar contra uma súmula do Supremo? Como advogados, devemos decidir, taticamente, se vamos ou não.

Nosso curso é teórico, é para exercitar o raciocínio jurídico; no final do curso ouviremos nossos colegas dizerem que 'Giannini está errado nisso, que Rubens Gomes de Souza está errado naquilo', isto porque vamos adquirir condições de raciocínio e, portanto, aprendendo com essas pessoas e com o Supremo, muitas vezes vamos ter, em nós mesmos, segurança suficiente para reconhecer quando essas grandes autoridades também não acertam. Nada escandaliza que o STF tenha decidido assim. É um problema prático. Aconteceu. Nosso propósito, aqui, é examinar a Constituição, procurando critérios objetivos, que, inclusive, permitam reconhecer onde há erro e onde há acerto, na legislação e na aplicação desta.

Prof. Paulo de Barros Carvalho - A prova disso é que o Supremo, muitas vezes, reformula posições" (in Interpretação no Direito Tributário. Org. B. Ribeiro de Barros, Coord. G. Ataliba. São Paulo, SaraivaEDUC, 1975, p. 75). 
pago indevidamente, quando reconhecido, por decisão, que o contribuinte de jure não recuperou do contribuinte de facto o quantum respectivo".

O indispensável exame da jurisprudência que a embasou revela que, contrariamente à nota contida na Súmula n. 546, ${ }^{68}$ manteve-se o entendimento do Supremo Tribunal Federal, antes resumido na Súmula n. 71, ${ }^{69}$ muito embora a maioria da doutrina, apegada unicamente à literalidade dos textos das duas súmulas, conclua no sentido de que "a Súmula 71, evidentemente, está ultrapassada, e a 546 guarda sintonia com o mandamento do art. $166 "{ }^{70}$

Isto porque os precedentes-paradigmas que consolidaram o texto da Súmula n. 546 referem-se a casos em que a Súmula n. 71 não podia ser aplicada, em virtude de que o contribuinte de direito havia comprovado que suportou o encargo financeiro do tributo, não se verificando o locupletamento a ensejar a aplicação do antigo enunciado do Supremo Tribunal Federal.

Rigorosamente, as Súmulas ns. 71 e 546 convivem sem uma excluir a outra, porquanto os dois enunciados, antes, complementam-se e reiteram o posicionamento do Supremo Tribunal em reconhecer apenas a figura do contribuinte "de direito": o enunciado n. 71 da Suprema Corte exige a prova negativa da repercussão econômica para que os tributos indiretos sejam restituídos; a Súmula n. 546, por outro lado, condiciona o reconhecimento da legitimidade para a repetição do indébito à prova positiva de que o autor da ação suportou o encargo financeiro do tributo impugnado.

Deveras, a parte final do art. 166 do Código Tributário Nacional pretende positivar a tese vinculada na vetusta Súmula n. 71, segundo a qual "embora pago indevidamente, não cabe restituição do tributo indireto", sendo explicitado no exame de seus precedentes-paradigmas o posicionamento da Suprema Corte, adotado pelo legislador da Lei n. 5.172/66, no sentido de reconhecer o direito do Estado de incorporar quantias indevidamente recolhidas ao seu patrimônio, na ausência de justo título que ampare

68 "Observação: A Súmula 71, que, desde sua instituição, vinha prevalecendo para os julgados do Supremo Tribunal Federal, que a aplicou em vários processos, foi, posteriormente, contrariada pelos julgamentos dos processos RE 45.977, 58.590 e ERE 58.660, cuja íntegra dos acórdãos damos a seguir, razão pela qual a douta Comissão de Jurisprudência, aceitando o trabalho elaborado pela excelsa Comissão para nova edição da Súmula, criou no Adendo 4, a Súmula 546" (apud JOSÉ MORSCHBACHER, Repetição do indébito cit., p. 94).

${ }^{69}$ Cf. JOSÉ MORSCHBACHER, Repetição do indébito cit., p. 54, nota de rodapé n. 23, e p. 55. Extrai-se a seguinte passagem do inteiro teor de um dos precedentes-paradigmas que embasaram a Súmula n. 546: "Não estamos modificando a Súmula [n. 71]. A Súmula fica de pé" (trecho do debate registrado nos autos do recurso extraordinário n. 58.290, 3. a Turma, Relator Ministro Luiz Gallotti, votação unânime, julgado em 23.11.1966, apud JOSÉ MORSCHBACHER, Repetição do indébito cit., p. 103) [interpolamos].

70 PAUlo BARROS CARVAlHO, Curso de Direito Tributário cit., p. 528. Cf. WALTER BARBOSA CORRÊA, "Jurisprudência Relativa à Repetição do Indébito Tributário na Vigência da Constituição de 1946”, in Cadernos de Pesquisas Tributárias - Tema 8: Repetição do Indébito. Coord. I. G. Silva Martins. São Paulo: Resenha Tributária, 1983, p. 350. 
o contribuinte de direito a pleitear a restituição do indébito tributário - fazendo prova negativa da repercussão, ou, no caso de ter transferido a terceiro, estar, pelo contribuinte de fato, expressamente autorizado para receber os valores indevidos -, devendo prevalecer o princípio da supremacia do interesse público.

Por qualquer ângulo que se examine a questão conclui-se que as Súmulas ns. 71 e 546 do Supremo Tribunal Federal, assim como o texto do art. 166 do Código Tributário Nacional, não reconhecem a figura do contribuinte "de fato", mesmo que prove ter suportado o encargo financeiro da percussão tributária.

Repita-se, à exaustão: em nenhum momento foi reconhecida pela Constituição ou pela legislação infraconstitucional a figura do contribuinte "de fato", motivo pela qual reiteramos a conclusão de que a imunidade tributária das entidades de assistência social não pode alcançar situações em que essas entidades são tidas como contribuintes "de fato" em relação aos seus fornecedores no contexto de uma suposta "repercussão econômica" dos impostos.

\section{3. - Similitude da Jurisprudência Acerca da Imunidade Recíproca}

O tema trazido a estudo possui similitude fática e jurídica aos debates produzidos pelos Ministros Aliomar Baleeiro e Bilac Pinto no Supremo Tribunal Federal acerca da extensão dos benefícios da imunidade recíproca ao produtor, fornecedor de bens e serviços contratados por entes públicos, enfocando-se a jurisprudência justamente sobre a peculiaridade do ente público suportar as consequências decorrentes de ser contribuinte de "fato". 71

De um lado, o Ministro Aliomar Baleeiro sustentava a tese segundo a qual as pessoas de Direito Público poderiam impetrar mandado de segurança e se opor ao pagamento do imposto sobre consumo exigido de fabricantes ou outros contribuintes de direito pelos fornecimentos que lhes fizessem, porque o imposto sobre consumo, por ser tributo indireto, tem seu impacto repercutido sobre o comprador, contribuinte de "fato". Se, então, a pessoa de Direito Público estiver na posição de consumidor, não haveria tributo a ser pago pelo produtor, fornecedor, em razão da imunidade tributária recíproca. ${ }^{72}$

71 "A polêmica em torno do alcance da imunidade recíproca das pessoas políticas em relação aos impostos indiretos é a maior já enfrentada pelo Excelso Pretório. O elevado grau de divergência, fecundada pelos notáveis debates realizados entre os Ministros Aliomar Baleeiro e Bilac Pinto, defensores de opiniões diametralmente opostas, bem demonstra ter siso essa a questão que mais ocupou o Supremo Tribunal Federal dentro do tema das imunidades fiscais até hoje" (REGINA HELENA COSTA, Imunidades Tributárias cit., p. 239).

72 "O fundamento da imunidade está nitidamente traçado pelo gênio de J. Marshall, há século e meio, em Mac Culloch vc. Maryland, de 1819, quando a Ciência das Finanças ainda se achava no berço. O poder de tributar pode ser também o de destruir. [...] Pouco importa que a lei ordinária diga que o contribuinte de 
Em contraposição, o Ministro Bilac Pinto relatou e produziu voto-condutor em célebre precedente no qual o impetrante do mandado de segurança era o Serviço Funerário do Município de São Paulo, escancarando a discordância à tese da "realidade econômica" sustentada pelo Ministro Aliomar Baleeiro, ${ }^{73}$ porque a figura do contribuinte de "fato" é estranha à relação jurídica tributária, sendo a divergência solucionada em 15.12.1976, com a edição da Súmula n. 591 pelo Plenário do Supremo Tribunal Federal, desde então em vigor:

\author{
SÚMULA STF 591 - A imunidade ou a isenção tributária \\ do comprador não se estende ao produtor, contribuinte do \\ Imposto sobre Produtos Industrializados.
}

\title{
3.4. - Precedente-Paradigma e Leading Case
}

Especificamente no que concerne às entidades de assistência social, desde 11.11.2008 vigora a manifestação do Ministro Gilmar Ferreira Mendes que, no exercício da Presidência do Supremo Tribunal Federal, decidiu contra a Casa de Caridade de

iure é o fabricante e que o ônus lhe incumbe. Em Direito Tributário, sobre relevo o elemento econômico, a realidade econômica, e não a roupagem jurídica. Quem suportará, efetivamente, o imposto aplicado a equipamento adquirido pelo Município de São Paulo? Ou lance em separado do preço ou neste o integre veladamente, o tributo é componente desse preço, com a matéria prima, a mão de obra, as despesas gerais da empresa, o lucro desta. Se o imposto é, por exemplo, de $30 \%$, o fabricante não irá suportar por patriotismo esse gravame. Ele o adicionará ao outro, como fator deste, e sobre a soma total acrescerá o seu lucro, sobretudo do contribuinte de facto, no caso - o Município." (STF, 1 a T, RE n. 68.144/SP, Rel. Min. Aliomar Baleeiro, j. 07.11.1969, v.u., DJ 29.12.1969). Cf. ALIOMAR BALEEIRO, Direito Tributário Brasileiro, 11. ed., Rio de Janeiro: Forense, 2000, p. 132/136; Memória Jurisprudencial: Ministro Aliomar Baleeiro, Brasília: Supremo Tribunal Federal, 2006, p. 134-140.

73 "Conheço do recurso por ser manifesta a divergência jurisprudencial. Em numerosos acórdãos [...] o Supremo Tribunal Federal vinha reconhecendo que a imunidade recíproca estabelecida no art. 19, II, letra 'a' e seu par. $1^{\circ}$ da Constituição de 1969, tornava os Estados e Municípios, bem como suas autarquias, não sujeitos ao pagamento do imposto sobre produtos industrializados que incidisse sobre bens por eles adquiridos. Essa orientação jurisprudencial foi recentemente alterada pelo Tribunal Pleno, nos julgamentos dos [...]. Nessas decisões, por sete votos contra três, o Tribunal Pleno decidiu que a imunidade fiscal recíproca não tem aplicação na cobrança do imposto sobre produtos industrializados, por isso que o contribuintes de iure é o industrial ou produtor. Nas decisões anteriores havia predominado o ponto de vista de que a realidade econômica poderia ser oposta à forma jurídica, para o fim de identificar o contribuinte de fato, embora estranho à relação tributária, e, em consequência, excluir a obrigação fiscal se se tratasse de pessoa jurídica de direito público, compreendida na regra da imunidade recíproca. Nos acórdãos recentes, ficou assentada a tese contrária, isto é, que não se pode opor à forma jurídica a realidade econômica e que a relação jurídica se estabelece unicamente entre o poder tributante e o contribuinte ou o responsável, nos termos da lei. De acordo com a nova interpretação, a figura do contribuinte de fato passou a ser considerada estranha à relação jurídica tributária, não podendo nela intervir, a qualquer título, para alegar que tem a seu favor a imunidade recíproca" (STF, 2 ${ }^{\mathrm{a}}$ T., RE n. 68.741/SP, Rel. Min. Bilac Pinto, j. 28.09.1970, v.u., DJ 27.11.1970). Reiterando nos nossos dias o precedente do Ministro Bilac Pinto [RE n. 71.300], v. STF, AI n. 844.401/MG, Rel. Min. Ayres Britto, j. 19.08.2011, DJe 12.09.2011; e CARVALHO, Paulo de Barros. Curso de Direito Tributário. cit., p. 238 e 239. 
Muriaé - Hospital São Paulo, em leading case [Suspensão de Segurança n. 3.533/MG] que invoca precedente-paradigma [Embargos de Divergência em Recurso Extraordinário n. 210.251-2/SP], assim:

“A decisão impugnada, ao determinar a suspensão da exigibilidade de recolhimento de ICMS nas aquisições de insumos, medicamentos e serviços inerentes ao funcionamento da instituição hospitalar, afeta negativamente a arrecadação da requerente [Fazenda do Estado de Minas Gerais], ante a relevância desse tributo no total da arrecadação estadual, gerando grave lesão à economia pública.

Diferentemente do exposto pela Casa de Caridade de Muriaé (petição n. 78.063 fls. 283-287), a matéria debatida na origem é distinta da que foi objeto da jurisprudencia desta Corte quanto à imunidade do ICMS, trazida à baila por aquela entidade às fls. 286-287. É que a jurisprudência desta Corte fixou entendimento de que se aplica a imunidade do art. 150, VI, c, CF/88, em relação ao ICMS, quando a entidade filantrópica seja a contribuinte de direito e comercialize bens, cujo ganho retorne integralmente para a realização da atividades da entidade. É este o caso dos Embargos de Divergência no Recurso Extraordinário $n$. 210.251-2/SP, em que se buscava a imunidade ao pagamento de ICMS referente à comercialização de pães produzidos por entidade filantrópica. Apenas nesse sentido houve a fixação do entendimento da existência de imunidade. [...]

No caso em questão, a entidade filantrópica não busca a imunidade sobre a comercialização de bens por ela produzidos, mas sim a imunidade de ICMS cobrado aos seus fornecedores (contribuintes de direito), e a ela repassados como consumidora (contribuinte de fato). Dessa forma, a manutenção da decisão impugnada pode ensejar grave lesão à ordem pública, pois se afasta o pagamento de ICMS, a titulo de imunidade tributária, sem expressa disposição constitucional nesse sentido. Também está presente a probabilidade de concretização do denominado 'efeito multiplicador' (SS-AgR 1.836, Rel. Carlos Velloso, DJ 11.10.2001), ante a possibilidade de concessão de medidas liminares em demandas que contenham o mesmo objeto.

Ante o exposto, defiro o pedido para suspender o acórdão proferido no mandado de segurança 1.0000.08.470001- 
2/000 em trâmite no Tribunal de Justiça do Estado de Minas Gerais." 74

Conclui-se que a razão determinante para que não fosse reconhecida pelo Ministro Gilmar Mendes a imunidade da entidade beneficente é a circunstância de que ela não é a fornecedora dos bens ou a prestadora de serviços (contribuinte "de direito"), mas destinatária (contribuinte "de fato", que suporta o ônus final do imposto) das mercadorias e serviços:

"No caso em questão, a entidade filantrópica não busca a imunidade sobre a comercialização de bens por ela produzidos, mas sim a imunidade de ICMS cobrado aos seus fornecedores (contribuintes de direito), e a ela repassados como consumidora (contribuinte de fato). Dessa forma, a manutenção da decisão impugnada pode ensejar grave lesão à ordem pública, pois se afasta o pagamento de ICMS, a titulo de imunidade tributária, sem expressa disposição constitucional nesse sentido".

Esquadrinhando-se a jurisprudência do Supremo Tribunal Federal, concluise que esse pronunciamento do Ministro Gilmar Ferreira Mendes - ao invocar o resultado do julgamento dos "Embargos de Divergência no Recurso Extraordinário n. 210.251-2/ SP” - está em sintonia com uma vetusta Súmula STF 591, cuja similitude fática e jurídica é em tudo aplicável.

Nos mencionados "Embargos de Divergência no Recurso Extraordinário n. 210.251-2/SP”, a Instituição Beneficente Lar de Maria postulou o reconhecimento de sua imunidade, prevista no art. 150, inciso VI, alínea “c” da Constituição da República para não ser compelida ao pagamento de ICMS cobrado em sede de execução fiscal, apurado na comercialização de pães produzidos pela referida entidade beneficente.

Ao final dos debates, que resultou no acórdão de 50 (cinquenta) laudas, apenas os Ministros Moreira Alves, Celso de Mello e Ellen Gracie não reconheceram a imunidade da Instituição Beneficente Lar de Maria, que mantiveram o entendimento segundo o qual o ICMS não onera a renda auferida pela entidade para a manutenção de seus objetivos institucionais, uma vez que repercute economicamente no consumidor, que é quem arca com o tributo, constituindo este o verdade beneficiário da imunidade (ratio decidendi adotada pelos Ministros Moreira Alves ${ }^{75}$ e Celso de Mello), resultando

\footnotetext{
74 STF, Suspensão de Segurança n. 3.533/MG, Rel. Min. Presidente, j. 11.11.2008, DJe 17.11.2008, in Revista Dialética de Direito Tributário v. 161, São Paulo: Dialética, Fev-2009, p. 180/182.

75 A respeito dessa questão específica, confira-se a combatividade dos debates no julgamento:

"O Senhor Ministro NELSON JOBIM - [...] Creio que essa leitura que sai dessa discussão, a meu ver, economicamente equivocada, falar-se em contribuinte de fato e contribuinte de direito, quando, absolutamente, não é verdade. Economicamente não é verdadeiro que toda compra, no preço você está
} 
em ameaça à livre concorrência, porque "caso agraciada com a imunidade em relação ao ICMS, poderá a instituição filantrópica vender o bem a um preço inferior ao praticado no mercado. Colocar-se-á, por certo, em posição privilegiada em relação a seus concorrentes. Não é este, todavia, o escopo da norma constitucional instituidora da imunidade" (votovencido da Ministra Ellen Gracie).

Os Ministros Gilmar Mendes, Sepúlveda Pertence, Nelson Jobim, Carlos Velloso, Sydney Sanches, Maurício Correa e Marco Aurélio votaram favoravelmente ao pedido da entidade beneficente, para que deixasse de pagar o ICMS, apurado na qualidade de fornecedora (contribuinte de direito) dos pães comercializados, prevalecendo o acórdão originário, julgado pela Segunda Turma e relatado pelo Ministro Carlos Mario Velloso, ${ }^{76}$ assim ementado:

$\begin{array}{lll}\text { "CONSTITUCIONAL. TRIBUTÁRIO. ICMS. } & \text { TCOÃO } \\ \text { IMUNIDADE TRIBUTÁRIA. INSTITUIÇA } & \text { DE }\end{array}$

cobrando tributo. Tanto é verdade que temos várias hipóteses em que uma empresa, sem condição de concorrência no mercado, o que faz? A primeira coisa é deixar de contribuir, de pagar os impostos. Fica inadimplente o tributo para manter um custo de produção compatível com o preço de venda. Isto ocorre principalmente no combate aos oligopólios.

O Senhor Ministro MOREIRA ALVES - Invocar um ato ilícito para essa sustentação, data venia, é um pouco exagerado. [...]

O Senhor Ministro NELSON JOBIM - Como V. Exa. sabe que o tributo é transferido para terceiro? V. Exa., já fez o cálculo do custo da produção? Do valor de venda? Já verificou se o preço de venda se fixa pelo custo da produção?

O Senhor Ministro MOREIRA ALVES - V. Exa. já fez?

O Senhor Ministro NELSON JOBIM - Não. Isso é uma tese econômica correta. Isso, em economia, é absolutamente pacífico.

O Senhor Ministro MOREIRA ALVES - Significa que eles terão prejuízo?

O Senhor Ministro NELSON JOBIM - V. Exa. comete um equívoco econômico quando sustenta que custo de produção e preço de venda são a mesma coisa. Não são.

O Senhor Ministro MOREIRA ALVES - Ninguém está dizendo isso."

76 Nos debates do julgamento dos Embargos de Divergência no Recurso Extraordinário n. 210.251-2/SP, o Ministro NELSON JOBIM cometeu a involuntária indiscrição de mencionar que "sabemos que nem todas as entidades contam, por exemplo, com o auxílio do Ministro Carlos Velloso - caso da atividade de assistência social que o Ministro Carlos Velloso desenvolve em relação a uma entidade assistência de Brasília. Nem todos têm o Ministro Carlos Velloso para resolver [sic] seus problemas".

Confidenciou o Ministro CARLOS VELLOSO em seu pronunciamento "já que o eminente Ministro Jobim revelou participação modesta minha na ajuda a necessitados, na ajuda a instituição de assistência social, desejo dar um depoimento: a grande maioria dessas instituições de assistência social, que acolhem crianças abandonadas, que acolhem idosos, realizam, na verdade, com as maiores dificuldades, tarefa que cabe ao Estado. Assim, quando o Estado confere a essas instituições imunidade tributária, não o faz gratuitamente. Simplesmente retribui o muito que essas instituições fazem pelos necessitados, tarefa, repito, que cabe ao Estado. [...] De regra, Sr. Presidente, essas instituições de assistência social vivem esmolando e só sobrevivem em razão do idealismo e da vontade de servir de seus dirigentes. Afirmar que uma entidade de assistência social preenche os requisitos da lei - o que está comprovado, no caso, as instâncias ordinárias isso afirmam - estaria disputando com vantagem no mercado, porque vende pãezinhos a certas entidades públicas, é ir longe demais. Comungo, no ponto, da santa ira de que foi tomado o ilustre patrono da instituição. É que S. Exa. deve conhecer, de perto, a instituição ora sob julgamento". 
EDUCAÇÃO SEM FINS LUCRATIVOS. C.F., ART. 150, $\mathrm{VI}$, 'C'.

I. - Não há invocar, para o fim de ser restringida a aplicação da imunidade, critérios de classificação dos impostos adotados por normas infraconstitucionais, mesmo porque não é adequado distinguir entre bens e patrimônio, dado que este se constitui do conjunto daqueles. $O$ que cumpre perquirir, portanto, é se o bem adquirido, no mercado interno ou externo, integra o patrimônio da entidade abrangida pela imunidade.

II. - Precedentes do STF: RE 203.755-ES, RE 87.913-SP, RE 89.173-SP, RE 88.671-RJ, RE 193.969-SP, RE 186.175SP e RE 225.671 (AgRg) - SP.”

De qualquer forma, embora na qualidade de contribuinte "de direito" (fornecedora/fabricante/prestadora de serviço) a entidade tenha obtido o reconhecimento da imunidade, por outro lado, nos debates é claro o posicionamento que não reconhece a imunidade quando a entidade de assistência social é o contribuinte "de fato", adquirente de mercadorias/bens ou tomadora de serviços, em similitude à Súmula STF n. 591, embora não tenha sido mencionada na sessão plenária:

O Senhor Ministro Sepúlveda Pertence - V. Exa. aceita a imunidade quando o ente público é comprador? Não. Aceitou-se isso no Supremo Tribunal Federal, mas há muito tempo se abandonou o entendimento. E a recíproca há de ser afirmada. Muito tempo se reconheceu aos Estados, por exemplo, a imunidade do IPI, quando adquiria automóvel, porque era contribuinte de fato. Em determinado momento, o Tribunal infletiu-se na orientação oposta, a partir, salvo engano, de um acórdão do Ministro Bilac Pinto. Ora, aqui estamos mudando o critério, conforme a situação.

O julgamento desses embargos de divergência, de 26 de Fevereiro de 2003, pelo Plenário do Supremo Tribunal Federal, deveria impedir que uma mesma regra de direito - no caso, o art. 150, inciso VI, alínea "c" da Constituição da República - fosse interpretado de maneiras diferentes pelos Ministros ou Turmas do mesmo Supremo Tribunal Federal, porque, conforme advertia o Professor Alfredo Buzaid - que teve assento na Suprema Corte (30.03.1982 - 20.07.1984) - "a certeza do direito está em evitar, simultaneamente, interpretações diversas e até antagônicas dadas pelos tribunais sobre a mesma regra de direito. [...] Não se trata, pois, de aderir a vários precedentes judiciários, porque eles podem ser contraditórios, mas sim de aderir a um precedente judiciário único, que seja observado como regra e assim deve prevalecer, enquanto não 
substituído por outro precedente judiciário único, que atenda a novas condições políticas, sociais e econômicas". ${ }^{77}$

Sub incerto enim iure nemo bonorum aut animae securus vivit (sob um direito incerto, ninguém vive seguro dos bens ou da vida ${ }^{78}$ ).

Desde 2003, quando ocorreu o julgamento dos referidos embargos de divergência, a composição do Supremo Tribunal Federal foi modificada, ingressando 11 (onze) $)^{79}$ novos Ministros, que compõem o Plenário (art. 101 da Constituição da República).

77 “Uniformização da Jurisprudência", in Revista AJURIS, v. 34, Porto Alegre, 1985, p. 192/193.

78 O Superior Tribunal de Justiça ao reacender controvérsia sobre matéria recém uniformizada com a edição da Súmula n. 276 ensejou o desabafo do Ministro HUMBERTO GOMES DE BARROS, ex-presidente do próprio STJ, no célebre julgamento do Agravo Regimental em Recurso Especial n. 382.736/SC (DJU de 25.02.2004):

"Nós somos os condutores, e eu - Ministro de um Tribunal cujas decisões os próprios Ministros não respeitam - sinto-me, triste. Como contribuinte, que também sou, mergulho em insegurança, como um passageiro daquele vôo trágico em que o piloto que se perdeu no meio da noite em cima da Selva Amazônica: ele virava para a esquerda, dobrava para a direita e os passageiros sem nada saber, até que eles de repente descobriram que estavam perdidos: O avião como o Superior Tribunal de Justiça está extremamente perdido. Agora estamos a rever uma Súmula que fixamos há menos de um trimestre. Agora dizemos que está errada, porque alguém nos deu uma lição dizendo que essa Súmula não devia ter sido feita assim.

Nas praias de turismo, pelo mundo afora, existe um brinquedo em que uma enorme bóia, cheia de pessoas é arrastada por uma lancha. A função do piloto dessa lancha é fazer derrubar as pessoas montadas no dorso da bóia. Para tanto, a lancha desloca-se em linha reta e, de repente, descreve curvas de quase noventa graus. O jogo só termina, quando todos os passageiros da bóia estão dentro do mar. Pois bem, o STJ parece ter assumido o papel do piloto dessa lancha. Nosso papel tem sido derrubar os jurisdicionados".

Em outro precedente, o mesmo Ministro HUMBERTO GOMES DE BARROS reiterou sua frustração: "o Superior Tribunal de Justiça foi concebido para um escopo especial: orientar a aplicação da lei federal e unificar-lhe a interpretação, em todo o Brasil. Se assim ocorre, é necessário que sai jurisprudência seja observada, para se manter firme e coerente. Assim sempre ocorreu em relação ao Supremo Tribunal Federal, de quem o STJ é sucessor, nesse mister. Em verdade, o Poder Judiciário mantém sagrado compromisso com a justiça e a segurança. Se deixarmos que nossa jurisprudência varie ao sabor das convicções pessoais, estaremos prestando um desserviço a nossas instituições. Se nós - os integrantes da Corte - não observamos as decisões que ajudamos a formar, estaremos dando sinal, para que os demais órgãos judiciários façam o mesmo. Estou certo de que, em acontecendo isso, perde sentido a existência de nossa Corte. Melhor será extingui-la" (STJ, Corte Especial, AgREsp. n. 228.432/RS, Rel. Min. Humberto Gomes de Barros, j. 01.02.2002, v.u., DJ 18.03.2002, p. 163, RNDJ 29/151, RSTJ 127/17, reiterado no voto-vista proferido nos autos do AgREsp. n. 382.736/SC, Rel. Min. Castro Meira, Rel. p/ acórdão Min. Francisco Peçanha Martins, j. 08.10.2003, DJ 25.02.2004, p. 91).

Cf. EDUARDO CAMBI, "Jurisprudência Lotérica", in Cidadania e Justiça - Revista da Associação dos Magistrados Brasileiros. Ano 5, n. 11. Brasília: $2^{\circ}$ Semestre/2001, p. 193-211; JOSÉ ROGÉRIO CRUZ E TUCCI, Precedente Judicial como Fonte do Direito. São Paulo: Revista dos Tribunais, 2004, p. 267; JOSÉ CARLOS BARBOSA MOREIRA, Comentários aos Código de Processo Civil, v. V, 14. ed., Rio de Janeiro: Forense, 2008, p. 16.

79 Antonio Cezar Peluzo (25.06.2003), Carlos Augusto Ayres de Freitas Britto (25.06.2003), Joaquim Benedito Barbosa Gomes (25.06.2003), Eros Roberto Grau (30.06.2004), Enrique Ricardo Lewandowski (16.03.2006), Carmen Lucia Antunes Rocha (21.06.2006), José Antonio Dias Toffoli (23.10.2009), Luiz Fux (03.03.2011), Rosa Maria Weber Candiota da Rosa (19.12.2011), Teori Albino Zavascki (29.12.2012) e Luis Roberto Barroso (26.06.2013). A respeito da nomeação desses Ministros, Cf. RAYMUNDO COSTA e ROSÂNGELA BITTAR, "As Instâncias Para Chegar ao Supremo", in Valor Econômico, Caderno "Eu \& Fim de Semana", Ano 14, n. 657, 14 de Junho de 2013, p. 12 a 17. 
Apesar de não surgirem novas condições políticas, sociais e econômicas supervenientes que alterassem o contexto da interpretação da imunidade tributária das entidades de assistência social, colhe-se das recentes manifestações das Turmas do Supremo Tribunal Federal julgados que indeferem a pretensão de entidades assistenciais que invocam a circunstância em que são adquirentes de bens ou serviços (contribuinte "de fato"), em adesão ao pronunciamento do Ministro GILMAR FERREIRA MENDES no leading case:

“A imunidade do art. 150, VI, c, da Constituição somente se aplica ao imposto incidente diretamente sobre serviço, patrimônio ou renda do próprio ente beneficiado, ou seja, na qualidade de contribuinte de direito. No caso, como a entidade de assistência social é contribuinte de fato do ICMS relativamente aos bens e serviços pore la adquiridos no mercado interno, não faz juz a imunidade em questão. Precedentes."

(STF, $1^{\text {a }}$ T., AI 769.295/SP-AgR, Rel. Min Ricardo Lewandowski, j. 19.10.2010, DJe 16.11.2010)

No mesmo sentido: AI 717.793-AgR, Rel. Min. Cármen Lúcia, j. 15.02.2011, v.u, DJe 17.03.2011.

Apesar do leading case [Suspensão de Segurança n. 3.533/SP] permanecer sub judice e com resultado desfavorável, há alguns julgamentos dissonantes do Supremo Tribunal Federal no sentido de reconhecer a imunidade das entidades de assistência social para que deixem de pagar impostos "indiretos" na aquisição de mercadorias - desde que passem a integrar o seu patrimônio ou que tenham pertinência direta com sua finalidade essencial ( $\S 4^{\circ}$ do art. 150 da Constituição da República):

STF - $1^{\text {a Turma: }}$

“Tributário. ICMS. Imunidade. Operações de importação de mercadoria realizada por entidade de assistência social. (...) A jurisprudência da Corte é no sentido de que a imunidade

O Ministro Carlos Alberto Menezes de Direito tomou posse em 05.09.2007, falecendo precocemente em 01.09.2009; o Ministro Eros Roberto Grau foi aposentado, compulsoriamente, em 19.08.2010, quando completou 70 anos de idade; e à Ministra Ellen Gracie foi concedida antecipação da aposentadoria pelo Decreto Presidencial de 05 de Agosto de 2011, publicado no Diário Oficial de 08.08.2011. Os Ministros Cezar Peluso e Ayres Britto foram aposentados compulsoriamente, ao completarem 70 anos, em 2012, ambos e sucessivamente na presidência do Supremo Tribunal Federal e no curso do julgamento da Ação Penal n. 470.

Desde 2003, desligaram-se, também, do Supremo Tribunal Federal os Ministros Moreira Alves, Nelson Jobim, Sepúlveda Pertence, Mauricio Correa, Sidney Sanches, Neri da Silveira, Ilmar Galvão e Carlos Mario Velloso. 
prevista no art. 150, VI, c, da Constituição Federal abrange o ICMS incidente sobre a importação de mercadorias utilizadas na prestação de seus serviços especificos".

(STF, $1^{\text {a }}$ T., AI 669.257-AgR, Rel. Min Ricardo Lewandowski, j. 17.03.2009, v.u., DJe 17.04.2009)

No mesmo sentido: RE n. 377.024-AgR, Rel. Min. Cármen Lúcia, j. 22.09.2009, v.u, DJe 23.10.2009. ${ }^{80}$

STF - $2^{\mathrm{a}}$ Turma

"Na tributação das operações de importação, o contribuinte por excelência do tributo é o importador (que tende a ser o adquirente da mercadoria) e não o vendedor. Há confusão entre as figuras do contribuinte de direito e do contribuinte de fato. Assim, não faz sentido argumentar que a imunidade tributária não se aplica à entidade beneficente de assistência social nas operações de importação, em razão de a regra constitucional não se prestar à proteção de terceiros que arquem com o ônus da tributação."

(STF, 2 ${ }^{\mathrm{a}}$ T., AI 476.664-AgR, Rel. Min. Joaquim Barbosa, j. 06.04.2010, v.u. DJe 07.05.2010)

"ICMS. Imunidade. [...]. Aquisição de mercadorias e serviços no mercado interno. Entidade beneficente. A imunidade tributária prevista no art. 150, VI, c, da Constituição, compreende as aquisições de produtos no mercado interno, desde que os bens adquiridos integrem o patrimônio dessas entidades beneficentes."

(STF, 2a T., AI 535.922-AgR, Rel. Min. Ellen Gracie, j. 30.09.2008, v.u. DJe 14.11.2008)

No mesmo sentido: RE n. 540.725-AgR, Rel. Min. EROS GRAU, j. 10.02.2009, v.u., DJe 13.03.2009.

80 Do voto deste precedente, conclui-se que está presente a similitude fática e jurídica ao leading case, porém, com solução favorável:

"Alega o Agravante [Fazenda do Estado do Rio Grande do Sul] que, 'quando do julgamento do RE-EDv n. 201.251, Relator para acórdão o Min. Gilmar Mendes, DJ de 18.11.2003, há preeminência do contribuinte de direito para fins de fruição da imunidade. Nesse sentido, por não cuidar a hipótese de contribuinte de direito e, sim, de consumidor final, contribuinte de fato, não há como prosperar o entendimento manifestado pela r. decisão ora agravada'. [...] 1. Razão jurídica não assiste ao Agravante. 2. Como assentado na decisão agravada, não incide ICMS sobre a comercialização de mercadorias adquiridas pelas entidades de assistência social, em razão de estarem estas abrangidas pela imunidade tributária prevista no art. 150, inc. IV, alínea c, da Constituição da República. [...] 3. Os fundamentos do Agravante, insuficientes para modificar a decisão agravada, demonstram apenas inconformismo e resistência em por termo a processos que se arrastam em detrimento da eficiente prestação jurisdicional." [interpolamos] 
No contexto do Supremo Tribunal Federal, ainda é alto o grau de personalismo adotado nos julgamentos, conforme concluíram recentemente pesquisadoras da Escola de Direito de São Paulo da Fundação Getúlio Vargas. ${ }^{81}$

Permanece atual a comparação de Pietro Calamandrei do processo a um jogo, ao dizer que para obter justiça não basta ter razão, pois, além disso, conforme um antigo provérbio veneto, é preciso encontrar um juiz que a entenda e que tenha vontade de lhe dar razão. ${ }^{82}$

81 "Percebe-se que, em casos difíceis, é cobrado do STF um diálogo com as decisões anteriores, afinal os ministros são convocados a fixar um 'novo' entendimento para a decidibilidade de casos futuros. No entanto, às vezes, fica-se com a impressão de que há interesse apenas em fixar o 'novo', sem necessariamente remontar a jurisprudência do Tribunal de maneira adequada. Some-se a isso o fato de a jurisprudência constitucional não ser objeto de estudo sistemático por parte da academia. Não há, portanto, demanda por maior coerência do Tribunal. Mais do que atentar para o (não/mau) uso dos precedentes, parece necessário remontar as dificuldades da própria extração da linha argumentativa das decisões do Tribunal. Partindo-se da idéia de Dworkin de romance em cadeia, comparação feita pelo autor entre o processo de interpretação do direito e a literatura, fica-se com a impressão que o segundo capítulo de um romance em cadeia, em que o autor interpreta o capítulo que recebeu para então escrever o seu, é sempre interrompido. O que pretendemos com isso é alertar para a necessidade de uma continuidade, no tempo, no processo decisório. A teoria de Dworkin é útil na medida em que demonstra a necessidade de dialogo entre as decisões para que forme um entendimento coerente por parte da corte. Esse processo não visa engessar o processo criativo do juiz, atentando para a necessidade de sempre recorrer a casos antigos para formar seu convencimento. Pelo contrario, ele aponta para o fato de que uma corte que dialoga com suas próprias decisões pode obter melhor qualidade nestas, o que pode implicar em um processo interpretativo mais consolidado no tempo. [...] Para além da discussão do STF como um ator político, é preciso atentar para o seu funcionamento institucional, até mesmo para colocá-lo, também, sob o crivo público. Caso contrario, o STF, no sentido oposto que parece indicar seu recente 'ativismo' e flerte em ser um Tribunal constitucional, permanecerá um palco de disputas de solução de casos pontuais de maneira ad hoc, com um possível controle social apenas sobre a dimensão material e fática do caso. [...] Mesmo nos julgamentos por votação unânime há dificuldades em se determinar qual foi a decisão tomada pelo Tribunal como um todo, variando os julgamentos subsequentes à preferência pessoal do Ministro sorteado, circunstância representativa de uma falta de cultura de respeito aos precedentes judiciais do Supremo Tribunal Federal por seus próprios Ministros. Ainda que se entenda que o voto do ministro relator, que guia a tomada de decisão dos demais ministros, tem um peso maior na fundamentação do caso, podendo-se entender que a partir dele seria possível extrair a ratio decidendi, não há como deixar de considerar o fato de que fundamentações conflitantes com o voto do ministro relator relativizam a adequação dessa ratio decidendi ao que foi decidido pelo Tribunal. A unanimidade se dá tãosomente com relação ao dispositivo da decisão, o elemento questionado por meio da ADI, mas não se reflete no momento da justificação dessa solução dada pelo Tribunal. Uma consequência dessa peculiaridade da decisão do STF, que decorre do modo como se dá a tomada de decisão, é o alto grau de personalismo dotado aos seus julgamentos. Poder-se-ia falar em ratio do ministro, em uma linha de pensamento desenvolvida por ele e, inclusive, aplicação de precedentes individuais. Não há, especialmente nos casos que envolvem aplicação de princípios a possibilidade de extração de uma ratio coletiva, institucional" (ADRIANA DE MORAIS VOJVODIC, ANA MARA FRANÇA MACHADO E EVORAH LUSCI COSTA CARDOSO, "Escrevendo Um Romance, Primeiro Capítulo: Precedentes e Processo Decisório no STF", in Revista Direito GV 09, v. 5, n. 1, Jan-Jun. 2009, p. 27/31).

82 "Il Processo Come Giuoco", in Rivista di Diritto Processuale, 1950, p. 24/25, apud EDUARDO CAMBI, "Jurisprudência Lotérica", in Cidadania e Justiça - Revista da Associação dos Magistrados Brasileiros. Ano 5, n. 11. Brasília: $2^{\circ}$ Semestre/2001, p. 196. "É mister abandonar tanto o propósito de alcançar uma idéia universal de justiça como o de reduzi-la a um conjunto de perspectivas ou de requisitos formais, capazes de legitimar as relações jurídicas, pois ela é inseparável de sua concreta projeção na experiência. 
Diante da atual composição do Supremo Tribunal Federal e dos recentes pronunciamentos de suas Turmas, estimamos como "possivel" o entendimento favorável à imunidade da instituição de assistência social, sem fins lucrativos, em relação aos impostos indiretos que incidiriam sobre a aquisição de mercadorias - desde que, na condição de contribuinte "de fato", tais bens passem a integrar o seu patrimônio ou que tenham pertinência direta com sua finalidade essencial ( $\left(4^{\circ}\right.$ do art. 150 da Constituição da República).

Tratando-se de uma noção corrente e moente que o controle de constitucionalidade é inexoravelmente jurídico e político (porque até mesmo no sistema judiciário da common law "stare decisis is not, like the rule of res judicata, a universal inexorable command"83), tem toda razão Eros Roberto Grau ao confessar que tem "medo dos juízes", ${ }^{84}$ respeitada a autoridade e acatamento que sempre ensejaram os pronunciamentos do Supremo Tribunal Federal. ${ }^{85}$

Para dar apenas um exemplo, o suum cuique tribuere, longe de ser uma solução, é antes um enunciado de problemas, pois fica sempre de pé saber o que é seu de cada um, em sua individualidade concreta; como é possível atribuir algo a cada um sem se levar em conta o atribuível proporcionalmente aos demais; e, finalmente, como é que a atribuição pode e deve ser feita em razão das circunstâncias ocorrentes" (MIGUEL REALE, Nova Fase do Direito Moderno, 2. ed., $3^{\mathrm{a}}$ tir., São Paulo: Saraiva, 2010, p. 41).

83 US Supreme Court: Burnet v. Coronado Oil \& Gas Co., 285 US 393, 402 (1932), que reitera State of Washington v. W. C. Dawson \& Co., 264 US 219, 238 (1924) e mais recentemente, Harris v. US, 536 US 545, 556 (2002), Lawrence v. Texas, 539 US 558, 577 (2003); daí porque falar de precedente "vinculante" é enganoso.

84 "Coisa curiosa a vida. Eu era advogado, virei magistrado. Quando me transformaram em magistrado, disseram: 'Lá vem um esquerdista'; outros, mais claramente: 'Lá vem um comunista para desordenar tudo isso'. Após seis anos de judicatura, verifico que sou o mais empedernido dos positivistas. Porque sei que apenas o direito positivo permite, em última instância, a defesa dos oprimidos e das classes subalternas. Sem a lei, estamos perdidos. Sem o direito positivo não há liberdade. Tenho medo dos juízes porque hoje, com essa coisa da ponderação, essa coisa de ponderar valores, essa coisa de tomar o critério da proporcionalidade e o critério da razoabilidade como se fossem princípios, ficamos inteiramente entregues à subjetividade de cada um deles" "Interpretação da Lei Tributária e Segurança Jurídica" - Conferência no XXIV Congresso de Direito Tributário do Instituto Geraldo Ataliba - IDEPE, em 22.10.2010, in Revista de Direito Tributário, v. 113, p. 225). Cf. CARLOS ARI SUNDFELD, "Princípio é Preguiça?", in Direito Administrativo para Céticos, São Paulo: Malheiros, 2012, p. 60-84.

85 "The Constitucion is what the judges say it is" (Chief Justice Huges, apud RAUL MACHADO HORTA, Direito Constitucional, 4. ed., Belo Horizonte, Del Rey, 2003, p. 142; HERBERT L. A. HART, The Concept of Law, Oxford, 1961, trad. port. A. R. Mendes, O Conceito de Direito. 3. ed., Lisboa: Fundação Calouste Gulbenkian, 2001, p. 155).

Por ocasião de celebérrimo julgamento da Ação Penal n. 470, em 17.12.2012, o Ministro Celso de Mello, respondendo a ameaça de desobediência pelo presidente da Câmara dos Deputados Federais, enfatizou que "é preciso reafirmar a soberania da Constituição Federal e destacar a intervenção do STF, por expressa delegação do constituinte, de ter o monopólio da última palavra da interpretação da Constituição Federal. [...] O Legislativo não pode invocar monopólio de interpretações constitucionais, ajustadas a uma visão de conveniência. [...] Seria a subversão da vontade do constituinte inscrita no texto constitucional. [...] A insubordinação legislativa ou executiva revela-se comportamento intolerável, inaceitável ou incompreensível" (STF, "AP 470: deputados perderão mandato com o trânsito em julgado da decisão", disponível em http://www.stf.jus.br/portal/cms/verNoticiaDetalhe.asp?idConteudo=226883, acesso em 18.12.2012). 
Embora ainda esteja em vigor a Súmula STF n. 591, referido enunciado não é vinculante, tendo apenas efeito simbólico, já que os Ministros do Supremo Tribunal Federal podem desconsiderá-la, resolvendo as questões de direito em sentido contrário à súmula.

Por último, porque extrapola a nossa proposta de estudar o direito positivo vigente, cabe-nos aplaudir a reflexão de lege ferenda de Luis Eduardo Schoueri que, superando a errática jurisprudência e as disputas doutrinárias, aponta como solução jurídica para a controvérsia o legislador conceder "isenção" aos vendedores e prestadores não-imunes contratados pelas entidades de assistência social na aquisição de bens e serviços, haja vista que a "imunidade" não se faz suficiente para desonerá tais entidades beneficientes quando ostentam o pretenso predicado de contribuinte "de fato". ${ }^{86}$

\section{Conclusão}

Vemos, depois de tudo e finalizando, que o direito é uma realidade específica que deve ser apreendida por um conhecimento estrito - a ciência jurídica -, que não admite, pelo primado da unicidade de objeto, a aplicação de sincretismo de objetos de outras disciplinas, tal como a "Ciência" das Finanças, porquanto a realidade objetiva e a ciência (natural) - que descreve o mundo fenomênico - não guardam qualquer relação de pertinência à realidade jurídica-normativa que o jurista enuncia, seja no plano lógico de seus respectivos objetos (princípio da causalidade vs. relações de imputação), quanto de sua apreensão (lógica da consequência vs. lógica da preferência), bem como no plano da linguagem (o direito, necessariamente, ao assimilar um dado natural deformará seu conceito, em razão de sua realidade sistêmica, que exige uma relação de pertinência do seu repertório).

Improcede, portanto, aceitas nossas premissas, o entendimento que a Economia tenha qualquer repercussão na interpretação das normas e dos fatos jurídicos tributários (repercussão econômica no Direito Tributário): são inconfundíveis (a.1) o plano fenomênico (do evento econômico), assim como (a.2) o plano da ciência natural (que demonstra o fenômeno) do (b.1) plano normativo (jurídico) e do (b.2) plano da ciência do direito. Economia e suas repercussões não pertencem ao plano normativojurídico, logo, não são objeto de considerações no campo empírico-tributário da Ciência do Direito.

Pretendendo-se maximizar os efeitos da imunidade tributária, algumas entidades de assistência social sustentam a tese segundo a qual a desoneração tributária deve alcançar situações em que são tidas como contribuintes "de fato" de impostos

\footnotetext{
${ }_{86}$ Direito Tributário cit., p. 411.
} 
incidentes sobre operações contratadas com seus fornecedores, contribuintes "de direito" não-imunes.

Este, enfim, é o nosso objeto de análise: a questão é saber se há imunidade a impostos se o vendedor não é imune, mas o comprador é entidade de assistência social imune a impostos por força do art. 150, inciso VI, alínea “c” da Constituição da República.

Doutrina especializada sustenta a tese segundo a qual, por mais que o jurista repugne a noção de impostos "indiretos", eles existem, devendo ser ponderada a capacidade econômica do consumidor para efeito da definição do eventual ônus fiscal (pois ele será o contribuinte “de fato"); além disso, seria possível vislumbrar repertório jurídico (e não simplesmente econômico) que sinaliza o reconhecimento jurídico do contribuinte "de fato" ou consumidor final ao se verificar que $(i)$ a própria Constituição da República imprime noção da "capacidade contributiva" aos impostos ditos "indiretos" ao prever as regras da "não-cumulatividade" e da "seletividade de alíquotas" com vistas à sua nãooneração excessiva, tendo (ii) o legislador infraconstitucional reconhecido a juridicidade do fenômeno da "repercussão econômica" do tributo e da figura do contribuinte "de fato" ao prever o art. 166 do Código Tributário Nacional e tendo o Supremo Tribunal Federal referendado a existência do contribuinte "de fato" com a edição da Súmula n. 546.

Malgrado os qualificados argumentos, entendemos que não existe verificabilidade segura do fenômeno da "repercussão econômica dos tributos", razão porque a capacidade contributiva a considerar é a do contribuinte "de direito" porque é difícil e falaciosa a apreensão do fenômeno da "repercussão econômica" do tributo "indireto".

As referências à "não cumulatividade" à "seletividade das alíquotas" não são pertinentes ao tema da "imunidade tributária", porque pressupõem que o tributo já foi instituído, situando-se, portanto, no contexto do exercício da competência tributária, ao contrária da "imunidade tributária", em que a competência tributária já nasce tolhida em relação às pessoas protegidas por essa norma.

Em relação à "não-cumulatividade", o direito de abatimento de crédito não ilide a afirmação generalizada de que o ICMS é imposto "indireto", não possuindo o condão de convertê-lo em "imposto sobre o valor agregado", este sim poderia corroborar o argumento de que a "não-cumulatividade" teria como inspiração tutelar juridicamente o contribuinte "de fato".

A imunidade tributária às entidades de assistência social não contém qualquer norma indutora porque tais entes, limitando-se às suas finalidades essenciais, não estão no Domínio Econômico, e no que toca especificamente à "seletividade das alíquotas", tal instrumento não é pertinente para aferir "capacidade contributiva" do contribuinte "de fato", porquanto a "seletividade de alíquotas" varia apenas de acordo 
com a essencialidade do bem e não em virtude da etapa de circulação ou do destino ou do destinatário da mercadoria ou do serviço.

Finalmente, não se pode interpretar a Constituição mediante remissão à lei, mas, pelo contrário, só a lei pode ser interpretada à luz da Constituição. Não é possível inverter essa ordem.

Mesmo que se pudesse entender logicamente autorizado interpretar a Constituição mediante remissão à lei (e não o contrário: só a lei pode ser interpretada à luz da Constituição), verifica-se que as Súmulas ns. 71 e 546 do Supremo Tribunal Federal, assim como o texto do art. 166 do Código Tributário Nacional, não reconhecem a figura do contribuinte "de fato", mesmo que prove ter suportado o encargo financeiro da percussão tributária, razão pela qual a imunidade tributária das entidades de assistência social não pode alcançar situações em que essas entidades são tidas como contribuintes "de fato" em relação aos seus fornecedores no contexto de uma suposta "repercussão econômica" dos impostos.

Respondendo ao contencioso instaurado por tais entidades de assistência social o Supremo Tribunal Federal possui um precedente-paradigma (Embargos de Divergência em Recurso Extraordinário n. 210.251-2/SP) que informa superveniente leading case (Suspensão de Segurança n. 3.533/SP) ainda não julgado definitivamente, sinalizando a posição majoritária no sentido de que não é possível deferir o reconhecimento da imunidade nas situações em que as entidades de assistência social invocam a contingência de serem pretensamente contribuintes "de fato" nas aquisições de bens e serviços de vendedores, fabricantes e prestadores não-imunes, aplicando-se analogicamente a Súmula STF n. 591, editada nos casos de imunidade recíproca.

Julgados recentes não são uniformes quanto à adesão ao precedenteparadigma, ao leading case e à súmula, circunstância representativa de uma falta de cultura de respeito à jurisprudência do Supremo Tribunal Federal por seus próprios Ministros.

Neste contexto é bem vinda a reflexão da doutrina em propor de lege ferenda solução jurídica para a controvérsia com a intervenção do legislador concedendo "isenção" aos vendedores, fabricantes e prestadores não-imunes contratados pelas entidades de assistência social, haja vista que a "imunidade" não se faz suficiente para desonerar tais entidades quando ostentam o pretenso predicado de contribuinte "de fato".

São Paulo, Junho de 2013

Referências

AMARO, Luciano. Direito tributário brasileiro. 17. ed. São Paulo: Saraiva, 2011. 
ANGELOZZI, Adriana Marubayashi. A imunidade tributária das instituições de assistência social. 2005. Dissertação (Mestrado) - Faculdade de Direito, Pontifícia Universidade Católica de São Paulo.

FALCÃO, Amílcar Araújo. Fato gerador da obrigação tributária. Rio de Janeiro: Edições Financeiras, 1964.

. Introdução ao direito tributário brasileiro. Rio de Janeiro: Forense, 1999.

. Autonomia dos governos locais em matéria tributária. Revista de Direito Administrativo, n. 47 , p. $1-12$.

ATALIBA, Geraldo. Apontamentos de ciência das finanças, direito financeiro e tributário. São Paulo: Revista dos Tribunais, 1969.

. Hipótese de incidência tributária. São Paulo: Malheiros Editores, 1998.

. Autarquias e imposto do selo (diante da emenda constitucional n. 5). Separata da Revista dos Tribunais, v. 344, jun. 1964.

. Hermenêutica e sistema constitucional tributário. In: MORAES, B. Ribeiro de (Org.); ATALIBA, G. (Coord.). Interpretação no direito tributário. São Paulo: EDUC, 1975. p. 13-82.

- Propedêutica jurídica. In: ATALIBA, G. (Coord.). Elementos de direito tributário: notas taquigráficas do III Curso de Especialização em Direito Tributário, realizado na Pontifícia Universidade Católica de São Paulo. São Paulo: Revista dos Tribunais, 1978. p. 13-28.

BALEEIRO, Aliomar. Direito tributário brasileiro. 11. ed. rev. e atual. por F. B. Novelli. Rio de Janeiro: Forense, 1999.

- Limitações constitucionais ao poder de tributar. Revista, complementada à luz da Constituição de 1988 até a Emenda Constitucional n. 10/1996; e comentada por M. A. M. Derzi. Rio de Janeiro: Forense, 1998.

. Uma introdução à ciência das finanças. 14. ed., rev. e atual. por F. B. Novelli. Rio de Janeiro: Forense, 1993.

MELLO, Celso Antonio Bandeira de. Introdução. In: ATALIBA, G. (Coord.). Elementos de direito tributário: notas taquigráficas do III Curso de Especialização em Direito Tributário, realizado na Pontifícia Universidade Católica de São Paulo. São Paulo: Revista dos Tribunais, 1978. p. 1-11.

. O neocolonialismo e o direito administrativo brasileiro. In Curso de direito administrativo. 29. ed. São Paulo: Malheiros, 2012. p. 1.083-1.097.

. O princípio do enriquecimento sem causa em direito administrativo. In: Grandes temas de direito administrativo. São Paulo: Malheiros, 2009. p. 320.

BARACHO, José Alfredo de Oliveira. O enriquecimento injusto como princípio geral do direito administrativo. Revista dos Tribunais, v. 755, p. 11-75, 1998. 
CORREAA, Walter Barbosa. Jurisprudência relativa à repetição do indébito tributário na vigência da constituição de 1946. In: I. MARTINS, G. Silva (coord.). Cadernos de pesquisas tributárias - tema 8: repetição do indébito. São Paulo: Resenha Tributária, 1983. p. 339-378.

MOREIRA, José Carlos Barbosa. Comentários aos código de processo civil. v. 14. ed. Rio de Janeiro: Forense, 2008.

BARRETO, Aires F.; e BARRETO, Paulo A. Imunidades tributárias: limitações constitucionais ao poder de tributar. 2. ed. São Paulo: Dialética, 2007.

CARVALHO, Paulo de Barros. Curso de direito tributário. 22. ed. São Paulo, Saraiva, 2010.

. Direito tributário: fundamentos jurídicos da incidência. 2. ed. São Paulo: Saraiva, 1999.

. Direito tributário, linguagem e método. 2. ed. São Paulo: Noeses, 2009.

. Hermenêutica do direito tributário. In: ATALIBA, G. (Coord.). Elementos de direito tributário: notas taquigráficas do III Curso de Especialização em Direito Tributário, realizado na Pontifícia Universidade Católica de São Paulo. São Paulo: Revista dos Tribunais, 1978. p. 221-235.

- O objeto da ciência do direito e o papel do jurista: relações de derivação e positivação no sistema comunicacional do direito. In: DE SANTI, Eurico Marcos Diniz. Tributação e desenvolvimento: homenagem ao professor Aires Barreto (Coord.). São Paulo: Quartier Latin, 2011. p. 547-564.

. Impostos diretos e indiretos: sua natureza econômica e jurídica. In: Seminário para Avaliação do Sistema Tributário Nacional. Instituto Jurídico da Associação Comercial de São Paulo, 1982.

BECKER, Alfredo Augusto. Carnaval tributário. 2. ed. São Paulo: Lejus, 1999.

. Teoria geral do direito tributário. 2. ed. São Paulo: Lejus, 1998.

BEISSE, Heinrich. O critério econômico na interpretação das leis tributárias segundo a mais recente jurisprudência alemã. In: MACHADO, Brandão (Coord.). Direito tributário: estudos em homenagem ao prof. Ruy Barbosa Nogueira. São Paulo: Saraiva, 1984. p. 5-44.

. Interpretação. In: NOGUEIRA, R. B (dir.) e (col.). Estudos tributários. São Paulo: Resenha Tributária, 1974. p. 33-62.

BOTALLO, Eduardo Domingos. Fundamentos do IPI. São Paulo: Revista dos Tribunais, 2002.

- Restituição de impostos indiretos. Revista de Direito Público: Caderno de Direito Tributário, n. 22, , p. 314-332.

. Repetição do indébito tributário e o art. 166 do código tributário nacional. Revista de Direito Tributário, n. 75, p. 119-225.

. Repetição do indébito tributário e o art. 166 do código tributário nacional. Revista da Faculdade de Direito da Universidade de São Paulo, São Paulo, v. 94, p. 251-262, jan./dez. 1999. 
MACHADO, Brandão. Repetição do indébito tributário. In: MACHADO, Brandão (Coord.). Direito tributário: estudos em homenagem ao Prof. Ruy Barbosa Nogueira. São Paulo: Saraiva, 1984. p. 59-106.

MACHADO, Hugo de Brito. Temas de direito tributário. São Paulo: Revista dos Tribunais, 1993.

. Repetição do indébito tributário. In: MARTINS, I. G. Silva (Coord.). Cadernos de pesquisas tributárias: tema 8: repetição do indébito. São Paulo: Resenha Tributária, 1983. p. 231-252.

MACHADO, Hugo de Brito. Repetição do tributo indireto: incoerências e contradições. São Paulo: Malheiros, 2011.

BURKE, Peter. Confiança e a desconfiança no conhecimento: uma Coda. In: A Social History of Knowledge (from Gutenberg to Diderot). Oxford: Polity Press/Blackwell Publishers, 2000, trad. port. de P. Dentzien, Uma História Social do Conhecimento (de Gutenberg a Diderot). Rio de Janeiro: Jorge Zahar, 2000.

BUZAID, Alfredo. Uniformização da jurisprudência. AJURIS, Porto Alegre, v. 34, p. 192/193, 1985.

CAMBI, Eduardo. Jurisprudência lotérica. Cidadania e Justiça: Revista da Associação dos Magistrados Brasileiros, Brasília, a. 5, n. 11, p. 193-211, 2001.

CARrAZZA, Roque Antonio. Curso de direito constitucional tributário. 27. ed. São Paulo: Malheiros, 2011.

. ICMS. 11. ed. São Paulo: Malheiros, 2006.

CARVALHO, Aurora Tomazini de. Curso de teoria geral do direito: o construtivismo lógicosemântico. 2. ed. São Paulo: Noeses, 2010.

CARVALHO, Luis Gustavo Santana de. O alcance da norma jurídica constitucional tributária que imuniza o livro. Revista de Direito Tributário, v. 114, p. 122-123.

COMPARATO, Fábio Konder. Prefácio à terceira edição. In: O poder de controle na sociedade anônima. 3. ed. Rio de Janeiro: Forense, 1983. p. IX.

- Reflexões sobre o método do ensino jurídico. Revista da Faculdade de Direito da Universidade de São Paulo, São Paulo, v. LXXIV, São Paulo, p. 119-138, 1979.

COSTA, Alcides Jorge. Direito tributário e direito privado. In: MACHADO, Brandão (coord.). Direito tributário: Estudos em Homenagem ao Prof. Ruy Barbosa Nogueira. São Paulo: Saraiva, 1984. p. 221-237.

. Capacidade contributiva. Revista de Direito Tributário, v. 55, p. 302.

COSTA, Regina Helena. Imunidades tributárias: teoria e análise da jurisprudência do STF. 2. ed. São Paulo: Malheiros, 2006.

CRUZ E TUCCI, José Rogério. Precedente judicial como fonte do direito. São Paulo: Revista dos Tribunais, 2004. 
DENARI, Zelmo. A interpretação econômica do nosso sistema tributário. Revista de Direito Tributário, n. 55, p. 343-351.

DERZI, Misabel Abreu Machado. Finalmente, um retorno a Aliomar Baleeiro? O falso dilema entre interpretação jurídica ou econômica. In: BALEEIRO, Aliomar. Limitações constitucionais ao poder de tributar, p. 301-306.

. A imunidade recíproca, o princípio federal e a emenda constitucional n. 3, de 1993. Revista de Direito Tributário, v. 62, p. 96- 97.

. A interpretação impropriamente chamada 'econômica' e o respeito às formas, conceitos e institutos jurídicos. A tensão entre igualdade e segurança jurídica. In: BALEEIRO, Aliomar. Limitações constitucionais ao poder de tributar. p. 644-647 e 729-731.

EDMONDS, David; EIDINOW, John. Wie Ludwig Wittgenstein Karl Popper mit dem Feuerhaken drohte-Eine Ermittlung/Wittgenstein's Poker, Sttutgart/München: Deutsche Verlags-Anstalt, 2001, trad. port. de P. Jorgensen Jr., O Atiçador de Wittgenstein: A História de Uma Discussão de Dez Minutos entre Dois Grandes Filósofos, Rio de Janeiro: Difel, 2003.

FERNANDES, Luis Dias. Repetição do indébito tributário. 1995. Dissertação (Mestrado) Faculdade de Direito da Universidade de São Paulo, São Paulo.

FERRAZ JÚNIOR, Tércio Sampaio. A ciência do direito. 2. ed. São Paulo: Atlas, 1980.

. Função social da dogmática jurídica. São Paulo: Max Limonad, 1998.

. Introdução ao estudo do direito: técnica, decisão, dominação. 2. ed. São Paulo: Atlas, 1996.

FERREIRA, Waldemar. História do direito brasileiro. 2. ed. São Paulo: Saraiva, 1962. v. 1.

FORTES DE CERQUEIRA, Marcelo. Repetição do indébito tributário: delineamentos de uma teoria. São Paulo, Max Limonad, 2000.

FLUSSER, Vilém. Lingua e realidade. $3^{\text {a }}$ ed. São Paulo: Annablume, 2004.

SOUZA, Rubens Gomes de. Compêndio de legislação tributária. 2. ed. Rio de Janeiro: Edições Financeiras, s/d.

. Restituição de impostos indiretos. Revista de Direito Administrativo, v. 21, p. 24-40, jul./ set. 1950 .

GORDILlO, Agustin. Princípios gerais de direito público. Trad. port. M. A. Greco. São Paulo: Revista dos Tribunais, 1977.

GRAU, Eros Roberto. O direito posto e o direito pressuposto. 3. ed. São Paulo: Malheiros, 2000. . Interpretação da lei tributária e segurança jurídica. Conferência ao XXIV Congresso de

Direito Tributário - IDEPE, em 22.10.2010. Revista de Direito Tributário, v. 113, p. 220.

. Pareceres, Juristas e Apedeutas. Revista dos Tribunais, v. 777, p. 37-40, jul. 2000. 
GRUPENMACHER, Betina Treiger. Eficácia e aplicabilidade das limitações constitucionais ao poder de tributar. São Paulo: Resenha Tributária, 1997.

HART, Herbert L. A. The concept of law, Oxford, 1961. Trad. port. A. R. Mendes. O conceito de direito. 3. ed. Lisboa: Fundação Calouste Gulbenkian, 2001.

HERREN AGUILlAR, Fernando. Metodologia da ciência do direito. 2. ed. São Paulo: Max Limonad, 1999.

HOBBES, Thomas. Leviatã. 2. ed. Trad. port. de J. P. Monteiro; M. B. Nizza da Silva. São Paulo: Imprensa Nacional-Casa da Moeda, 1999.

HORTA, Raul Machado. Direito constitucional. 4. ed. Belo Horizonte: Del Rey, 2003.

JÈZE, Gaston. Cours de science et legislation financiers. 6. ed. Paris: Marcel Giard, 1923.

KIRAT, Thierry. Économie du droit. Paris: Éditions La Découverte, 1999.

LAUFENBURGER, H. La distinzione fra imposte dirette ed indirette. Rivista di Diritto Finanziario e Scienza delle Finanze e Rivista Italiana di Diritto Finanziario, Milano, p. 3-18, mar. 1954.

GONÇALVES, José Artur Lima; MARQUES, Márcio Severo. O direito à restituição do indébito tributário. In: MACHADO, H. Brito. (coord.). Repetição do indébito e compensação no direito tributário. São Paulo-Fortaleza: Dialética-ICET, 1999. p. 198-231.

LUZ, Gyordano Kelton Alves. Teoria da norma tributária imunizante. 2010. Dissertação (Mestrado) - Faculdade de Direito, Pontifícia Universidade Católica, São Paulo.

MENDES, Guilherme Adolfo. Direito e tradução. In: HARET, Florence; CARNEIRO, Jerson (Coord.). Vilém Flusser e juristas: comemoração dos 25 anos do grupo de estudos de Paulo de Barros Carvalho. São Paulo: Noeses, 2009. p. 225-226.

BARROS, José Eduardo Monteiro de. Interpretação econômica em direito tributário. In: BARROS, B. Ribeiro de (Org.); ATALIBA, G. (coord.). Interpretação no direito tributário. São Paulo: SaraivaEDUC, 1975. p. 169-180.

MÖRSCHBÄCHER, José. A restituição dos impostos indiretos. Porto Alegre: Editora Síntese, 1977. . Repetição do indébito tributário indireto. São Paulo: Dialética, 1998.

. Repetição do indébito tributário e compensação. In: MACHADO, H. Brito (Coord.). Repetição do indébito e compensação no direito tributário. São Paulo-Fortaleza: Dialética-Instituto Cearense de Estudos Tributários, 1999. p. 253-280.

COELHO, Sacha Calmon Navarro. Curso de direito tributário brasileiro. Rio de Janeiro: Forense, 2001.

. Imunidade tributária. Revista de Direito Tributário, v. 38, p. 247. 
Interpretação econômica em direito tributário: prevalência do conteúdo sobre a forma.

Impossibilidade no direito brasileiro: princípio da legalidade. Revista de Direito Tributário, n. 55, p. 180-193.

NOGUEIRA, Johnson Barbosa. A interpretação econômica no direito tributário. São Paulo: Resenha Tributária, 1982.

NOGUEIRA, Liz Coli Cabral. A consideração econômica no direito tributário. In: NOGUEIRA, R. B. (Dir.). (Col.). Estudos tributários. São Paulo: Resenha Tributária, 1974. p. 349-384.

NOGUEIRA, Ruy Barbosa. Curso de direito tributário. São Paulo: Saraiva, 1989.

. Impostos diretos e indiretos, entidades sem fim lucrativo. In: Imunidades: contra impostos na constituição anterior e sua disciplina mais completa na Constituição de 1988. 2. ed. São Paulo: Saraiva, 1992. p. 25.

POPPER. Karl R. A lógica da pesquisa científica. Trad. port. de L. Hegenberg; O. Silveira da Mota. 8. ed. São Paulo: Cultrix, 2000. (The logic of scientific discovery, 1959)

POSNER, Richard A. Economic analysis of law. Boston, Toronto, London: Little, Brown and Company, 1998.

REALE, Miguel. Lições preliminares de direito. 23. ed. São Paulo: Saraiva, 1996.

ROBLES, Gregório. $O$ direito como texto: quatro estudos de teoria comunicacional do direito. Barueri: Manole, 2005.

ROCHA, Silvio Luis Ferreira da. Terceiro setor. 2. ed. São Paulo: Malheiros, 2006.

ROSS, Alf. Direito e justiça. Trad. port. E. Bini, rev. A. L. Mascaro São Paulo: Edipro, 2000. (On Law and Justice, Berkeley: University of California Press, 1959).

ROTHMANN, Gerd Willi. O princípio da legalidade tributária. In: NOGUEIRA, Ruy Barbosa (Org.). Direito tributário: estudos de casos e problemas. São Paulo: José Bushatsky, Editor, 1974. p. 137-180.

SAMUELSON, Paul Anthony; NORDHAUS, Willian D. Economia. 14. ed. Trad. port. de E. Nobre Fontana e J. Pires Gomes. Lisboa: McGraw-Hill, 1993. (Economics, McGraw-Hill, 1992).

SELIGMAN, Edwin R. A. Théorie de la répercussion et de l'incidence de l'impôt. Trad. franc. de L. Suret. Paris: V. Giard \& E. Brière, 1910.

SCHOUERI, Luis Eduardo. Direito tributário. São Paulo: Saraiva, 2011.

. Normas tributárias indutoras e intervenção econômica. Rio de Janeiro: Forense, 2005.

MARTINS, Ives Gandra da Silva. Prefácio. In: AMARO, Luciano. Direito tributário brasileiro. 17. ed. São Paulo: Saraiva, 2011. p. 11.

MELO, José Eduardo Soares de. Curso de direito tributário. São Paulo: Dialética, 1997. 
. Interpretação e integração da legislação tributária. In: MARTINS, I. G. Silva (Coord.). Curso de direito tributário. 7. ed. São Paulo: Saraiva, 2000. p. 135-160.

BORGES, José Souto Maior. O problema fundamental da base empírica para a ciência do direito e seus reflexos em questões indecidíveis pela doutrina do direito tributário. Revista de Direito Tributário, n. 31, p. 147-161.

SUNDFELD, Carlos Ari. Fundamentos de direito público. 4. ed., São Paulo: Malheiros, 2003. . Direito administrativo para céticos. São Paulo: Malheiros, 2012.

TOMÉ, Fabiana Del Padré. A prova no direito tributário. 3. ed. São Paulo: Noeses, 2011/2012.

TORRES, Ricardo Lobo. As influências germâmicas no direito financeiro e tributário brasileiro. Revista de Direito Tributário, n. 73, p. 76-85.

ULHÔA CANTO, Gilberto de. Temas de Direito Tributário, v. 2. Rio de Janeiro: Alba, s/d. In: "Natureza Tributária da Taxa de Despacho Aduaneiro: Restituição de imposto indireto pago indevidamente", in Revista de Direito Público, n. 1, p. 98-114.

VOJVODIC, Adriana de Morais; MACHADO, Ana Mara França; CARDOSO, Evorah Lusci Costa. Escrevendo um romance, primeiro capítulo: precedentes e processo decisório no STF. Revista Direito GV 09, v. 5, n. 1, p. 27-31, jan/jun. 2009. 